\title{
ПАЛЕОАНТРОПОЛОГИЧЕСКИЕ МАТЕРИАЛЫ ИЗ МОГИЛЬНИКОВ ДОНЕЦКОЙ И ЛУГАНСКОЙ ОБЛАСТЕЙ. ЧАСТЬ I*
}

\begin{abstract}
Статья посвящена публикации краниологических материалов из могильника Маяки Донецкой области. Приводится краткое описание археологического памятника, особенностей погребального обряда и итоги исследования палеоантропологических материалов. Основной задачей является введение в научнылй оборот индивидуальных данных краниологической серии из могильника.
\end{abstract}

Ключевые слова: краниология, палеоантропология, средние века, погребальный обряд, археологический комплекс

Для цитирования: Ходжайов Т.К., Ходжайова Г.К., Фризен С.Ю. Палеоантропологические материалы из могильников Донецкой и Луганской областей. Часть I // Вестник антропологии, 2021. № 4. С. 357-381.

\section{Введение}

Целью данной статьи является публикация палеоантропологических материалов могильников, исследованных на одном из крупнейших памятников в среднем течении Северского Донца - «Царино городище» у с. Маяки. Анализ как археологических, так и палеоантропологических материалов был опубликован ранее (Ходжайов 2012). В рамках данной статьи публикуются индивидуальные данные, полученные нами в ходе исследования палеоантропологических материалов.

Памятник «Царино городище» у с. Маяки датируется VII - 3-й четв. XIV вв. Подробная история изучения представлена в вышеупомянутой статье, в связи с этим, приводим только некоторые итоги археологических исследований.

Данный памятник расположен в среднем течении реки Северский Донец, на крайней южной границе со степью приречных и буерачных лесов, в зоне смены границ биоценозов степи и лесостепи (Артюшенко 1970: С. 156-159, Швецзов 2006: 275-278), и представляет собой группу укрепленных и неукрепленных поселений. На небольшом участке, длиной около полусотни километров, зафиксировано несколько городищ, среди которых археологический комплекс у с. Маяки является одним из наибольших.

Ходжайов Тельман Касимович - д.и.н, главный научный сотрудник Центра физической антропологии ИЭА РАН. (Москва, Ленинский пр. 32-a). E-mail: telmkas@yandex.ru

Ходжайова Гальшира Кутузовна - д.и.н., независимый исследователь, г. Москва. E-mail: telmkas@yandex.ru

Фризен Сергей Юрьевич - к.и.н., научный сотрудник Центра физической антропологии ИЭА PAН. (Москва, Ленинский пр. 32-a). E-mail: frizents@iea.ras.ru 


\section{Основные результаты}

\section{Исследованные на территории могильника погребения по планиграфии раскопок можно разделить на следующие групाы:}

Раскоп I. На данном участке могильника было исследовано 50 ингумационных захоронений двух основных хронологических групп IX-X вв. и XIII - cep. XIV в. Два погребения могильника $(9,47)$, по-видимому, относятся к XI-XII вв. и предшествуют золотоордынским. Захоронения мусульманского кладбища, впущенные с верхних слоев памятника (иногда разрушая более ранние комплексы), расположены наклонными рядами вниз по склону с севера на юг. Они отличаются друг от друга формой могильных ям и деталями погребения умерших (половозрастные определения представлены в табл. 1 и 2). Выделяются три типа погребальных ям: с уступами вдоль длинных сторон, простые с прямыми стенками и ямы с подбоями. Процент взаимосвязи признаков положения умерших в разных видах ям дает разные результаты. Если в ямах с подбоями представлены в большинстве детские погребения, то в простых ямах и ямах с заплечиками захоронены взрослые. Есть и кенотафы.

Раскоп II. Погребения, выявленные здесь, по залеганию можно разделить на 2 группы: I группа - захоронены мелко, в простых ямах как более ранние, чем погребения II группы. II группа - захоронения в меловом материке, в узких ямах" (Швецьов 1988: 10).

Останец I. Выявлены два захоронения, форма могильной ямы не фиксируется, погребенные положены: п. 1 - вытянуто, на спине, п. 2 - слегка с поворотом на бок, головой на запад, северо-запад.

Останец II. Всего на этом участке памятника исследовано 79 погребений по обряду ингумации.

Приведенный выше детальный анализ захоронений по раскопам показывает наличие в них погребений разных хронологических групп. Основой для такого деления могут служить не только стратиграфические наблюдения, конструкция могильных сооружений, но и инвентарь, сопровождавший умерших. позволяющий датировать захоронения IX-X веками. Он подробно описан в вышеуказанной статье. Для характеристики погребального обряда ранней группы приведем описание типов захоронений.

Погребения первого типа. Погребение 44, P.I расположено в юго-западном секторе раскопа. Могильная яма, вероятно, имела овальную форму. Скелет погребенного плохой сохранности, раздавлен. Лежал вытянуто на спине, головой к западу, руки вдоль тела. В кисти левой руки найдена половинка арабского серебряного дирхема (Швецов, Приходнюк 1989: 12).

Погребения второго типа. Погребение 8, Р.Н кв. Э11, Щ11-12, В яме находилось 2 скелета: скелет 1 захоронен раньше скелета 2. Уложен на правом боку, слабо скорчен. Плохо сохранившийся череп лежал на правом боку, лицевой частью на восток, шейный отдел позвоночника сильно изогнут вниз, части ребер нет. Правая рука вытянута вдоль туловища к ногам. От левой руки сохранилась плечевая кость. Ноги слабо подогнуты так, что на правую положена левая. На ноги рядом с тазом скелета 1 уложен скорченный скелет 2. Скелеты ориентированы на Ю3. Положение на правом боку. Голова лежит на правой щеке, лицом к югу. Левая рука вытянута 
к коленям. Ноги подогнуты. Костяк 2 подзахоронен к костяку 1 спустя некоторое непродолжительное время. На левой височной кости костяка 2 находилась серьга салтовского типа с навесной бусиной (Швецзов 1988: 11).

Приведенные нами два типа ранних захоронений аналогичны другим погребениям. К первому типу наиболее близки погребения: 39, 49, 50, P.I и 9 - 12, P.Н. Для них характерны овальная форма и небольшая глубина могильных ям, западная ориентировка скелета. Ко второму типу ранних захоронений относятся погребения: 8, Р.И и 6, Р.I. Наиболее близки им погребения 3, 4, Р.Н. Для них характерны подквадратная или подовальная форма неглубокой могильной ямы, скорченное положение скелета, уложенного головой на запад.

Рассмотренные нами типы погребений отражают элементы погребального обряда, характерные для грунтовых могильников зливкинского типа чаще всего существующих в рамках VIII-X вв. или IX-X вв., захоронения второго этапа указывают на продолжение жизни на поселениях зливкинского типа в последующие столетия.

Погребения третьего типа. Погребение 9. Могильная яма узкая, длинная, вытянута по линии СВ-ЮЗ. В заполнении фиксируются следы деревянных плах, положенных вдоль. Скелет лежит вытянуто на спине, головой на юго- запад, лицом вверх, левая рука согнута в локте, кистью направлена к локтю правой. Правая согнута в локте, кистью к лицу. Безынвентарно. Аналогично данному третьему типу погребение 47. Возможно, к этому же типу относится п. 1, Останец 1. Хронологию существования погребений данного типа на памятнике из-за отсутствия в них находок трудно соотнести с определенным временным периодом, однако элементы погребального ритуала (положение скелета умершего вытянуто на спине, головой на запад, с характерным специфическим положением рук умершего), возможным отнесение данного комплекса к захоронениям XI-XII вв. (Артамонова 1963).

Погребения четвертого типа - в простой яме п.21, Р.І. Узкая подпрямоугольная яма, слегка расширяющаяся ко дну, длинной осью ориентирована по линии В-3. На глубине 0,85 м находился скелет человека, лежащий на боку. Это захоронение человека со сросшимся позвоночником, сильно изогнутым на отдельных участках. Под лопатками - наросшие бугры. На костях ног - наросты. Ориентирован на запад, лежит с разворотом на правый бок. Безынвентарно. Аналогичные конструктивные детали могилы и положение скелета зафиксированы в п. 12, Р.І и в погребениях 5, 6, P.H, а также в п.25, P.I, впущенном с поверхности.

Погребения пятого типа - ямы с заплечиками (или уступами). Погребение 23, P.I. Могильная яма с заплечиками, ориентирована по линии Ю3-СВ, Заплечики узкие (0,25 м), расположены вдоль длинных сторон ямы, на них - остатки досок (двух плах). Погребенный лежит вытянуто на спине, головой на запад, позвоночный столб изогнут. Голова на правой щеке, лицом к югу. Руки сложены на тазе, ноги скрещены в стопах. Безынвентарен. Полной аналогией данному типу погребения можно считать захоронения: 22, 36, 38 .

Погребения шестого типа - в ямах с подбоем и ступенькой наиболее характерны, если прослеживается конструктивно, для детских погребений могильника (4, $7,10,11,13,16.24 .37)$. Но есть и погребения взрослых в могилах с подбоями (п. 19 и 40). П. 19 со сложными элементами деревянных конструкций. Ступенька расположена с северной стороны (ширина 0,45 м) с небольшим наклоном переходит в узкую яму, подбой которой слабо выделен, но отгорожен досками, поставленными 
под углом, одна из досок, стоящих прямо, подпирала свод подбоя, закрывая вход. Погребенный лежит на дне ямы на спине, головой на запад, лицом вверх, левая рука согнута в локте и прижата к груди, а правая согнута так, что кисть находится возле лица. Безынвентарно. П. 40, Р.І впущено с уровня дернового слоя, могильная яма подпрямоугольная. В верхней части ямы - остатки деревянного перекрытия. Вдоль северной стенки - ступенька шириной 28 см. Вход в подбой закрыт плашками. Безынвентарно.

Мы считаем необходимым отметить своеобразие данных комплексов и их близость к погребениям не только Прикубанья, Северного Кавказа, но и памятникам Сибири и Тувы. Наличие данных погребений на могильнике не является случайным и единовременным явлением, а связано с целым комплексом материалов. отражающих элементы хозяйственной и культурной жизни оставившего его населения.

Предложенная типологическая характеристика погребений могильника, основанная на материалах раскопов I и II, дает представление не только о разновременности его формирования, но и о сложности и поливариантности типов погребальных обрядов. Так, для ранней группы погребений наиболее характерны простые конструкции могильных ям, небольшая глубина захоронений, иногда “скорченное” положение умершего, наличие редких находок (серьги, монеты, пряжки), что сближает данные захоронения по обряду со «зливкинской» группой могильников. От захоронений могильника “Зливки”раннего этапа, принадлежащих сельскому (хуторскому) населению Подонцовья (Швецов 2001: 110-111, Швецов 2001: 333-344), погребения, исследованные на Маяках, отличаются отсутствием рядом с умершими керамических сосудов и напутственной пищи. Не исключено, что данный элемент обряда постепенно исчезает или переосмысливается жителями городских поселений (Швецов 2001: 110-111, Швецов 2016: 333-344). Подобные захоронения уже исследованы на памятнике. Ближайшие им аналогии известны в материалах раскопок В.К. Михеева. Это захоронения «могильника № 3 (IX в.), расположенного в юго-западной части нижнего посада. Здесь открыто 38 погребений. Погребения совершались на глубине 60-130 см. Контуры могильных ям, как правило, не прослеживаются. Погребения ориентированы на запад, иногда с отклонениями на юг и северо-запад. Они уложены на спине, руки скрещены на животе или левая согнута в локте так, что кисть находится у подбородка. Как правило, погребения одиночны, инвентарь беден. Единичными являются находки салтовских сережек, подвесок, браслетов» (Михеев 1985: 17-18). Еще раз необходимо отметить нахождение погребений ранней группы в северо-западном секторе P.I: п. 39, 49, 50, или за его пределами - п.44, что может также указывать на их предшествование последующим захоронениям.

Сложна и многообразна типология погребений позднего этапа существования памятника, относящегося к золотоордынской эпохе. При рассмотрении погребений этого времени, как указывалось выше, было выделено три типа их: в простой яме тип четыре и их близкие аналогии; в яме с заплечиками - тип пять; в яме с подбоем тип шесть. Захоронения на участке могильника Останец II дают более однородную характеристику погребений, близких к пятому типу. Система расположения погребений рядами с севера на юг, ориентированных с отклонениями по линии В-3, сближает данные захоронения с погребениями золотоордынской эпохи по мусульманскому обряду. Захоронения третьего типа, хронологически предшествующие погребениям мусульманского кладбища, по-видимому, относятся к XI-XII векам. 
В таблицах (таблицы 3-5) краниологические материалы сгруппированы в соответствии с типами захоронений. Исходя из данных, представленных в таблицах, выявлена достоверная связь типов захоронений только с возрастом погребенных и с положением костяка. Взрослых хоронили в ямах с заплечиками, в простых ямах и очень редко - в ямах с подбоем.

Краниологическая серия состоит из 47 черепов различной сохранности (из них 9 детских, 2 юношеских, 17 мужских и 19 женских). Индивидуальные данные черепов представлены в таблицах 3-5. Некоторые измерения длинных костей представлены в таблицах 6 и 7. Подробный анализ палеоантропологического материала представлен в вышеуказанной статье, в рамках данной публикации приводим некоторые итоги исследования.

\section{Заключение}

Материалы исследования археологических материалов дают возможность датировать памятник VII - Зй четв. XIV вв. Захоронения в могильниках относятся не только к разным, сменяющим друг друга хронологическим периодам, но и к обрядам, присушим разным (возможно, конфессиональным) группам населения и разным антропологическим группам погребенных.

Наличие на одном участке исследованных могильников погребений с разным погребальным обрядом, по-видимому, говорит о функционировании участков могильника в разные хронологические периоды. На это указывают и выявленные случаи стратиграфических нарушений отдельных захоронений. Однако для разных хронологических групп или этапов могут быть свойственны не только одинаковые элементы погребальных обрядов, но и обряды, существующие во все хронологические периоды, имеющие черты разных конфессиональных групп.

Материалы антропологического анализа могильников подтверждают неоднородность населения городищ Подонцовья, сформировавшегося на основе местного праболгарского (зливкинского) и степного половецкого (?) населения XII - 1-й пол. XIII века. Согласно данным письменных источников, частичным компонентом является и аланское население IX-XI веков. Однако данных о заселении региона Среднего Подонцовья и близлежащих территорий в IX-XII вв. мусульманами, тем более в таком значительными количестве, нет. Ни византийские, ни тем более русские летописи не могли бы не заметить появления и внедрения такого важного политического и тем более конфессионального фактора в общественной жизни своих соседей.

Исследование выполнено в рамках темы НИР «Эволюционный континуум рода Ното». Подтема «Антропология древних и современных популяций».

Таблица 1

Происхождение, пол и возраст погребенных в могильнике Маяки (VIII-X вв.)

\begin{tabular}{c|l|c|c|c}
\hline $\begin{array}{c}\text { № } \\
\text { п/п }\end{array}$ & Происхождение & Датировка & Пол & Возраст, лет \\
\hline 1 & Раскоп ІІ, погребение 3 & VIII-X вв. & муж & $45-50$ \\
\hdashline & р.II, п.4 & $-/ /-$ & $-/ /-$ & $40-45$ \\
3 & р.II, п.10 & $-/ /-$ & $-/ /-$ & $20-25$ \\
\hline
\end{tabular}




\begin{tabular}{|c|c|c|c|c|}
\hline $\begin{array}{l}\text { № } \\
\text { п/II } \\
\end{array}$ & Происхождение & Датировка & Пол & Возраст, лет \\
\hline 4 & р.II, п.11 & $-/ /-$ & жен. & $20-25$ \\
\hline 5 & p.II, п.9 & $-/ /-$ & муж. & $35-40$ \\
\hline 6 & p.II, п.8 (костяк 1) & $-/ /-$ & жен & $35-40$ \\
\hline 7 & p.II, п.7 & $-/ /-$ & - & $14-16$ \\
\hline 8 & p.II, п.8 (костяк 2) & $-/ /-$ & - & $10-12$ \\
\hline 9 & 1990 р. І, п. 3 & $-1 /-$ & жен. & $30-35$ \\
\hline 10 & p.I, п. 1 & $-/ /-$ & жен. & $20-25$ \\
\hline 11 & 1988, р.II, п. 12 & $-/ /-$ & муж & $25-30$ \\
\hline 12 & p.I, п. 4 & $-/ /-$ & - & 20-30 мес. \\
\hline 13 & p.II, п. 2 & $-/ /-$ & - & $6-8$ \\
\hline 14 & p.I, п. 44 & VIII в. & муж. & $35-40$ \\
\hline 15 & 1988, Останец, п.1 & VIII-X вв. & $-/ /-$ & $25-30$ \\
\hline 16 & Останец, п.2 & $-1 /-$ & - & $10-12$ \\
\hline 17 & p.1 (пригород), п.4 & $-/ /-$ & жен. & $25-30$ \\
\hline 18 & 1988, п.2 (траншея слива орошения) & $-/ /-$ & муж & $20-25$ \\
\hline 19 & Р.1, яма 1 (пригород) & $-1 /-$ & жен. & $20-30$ \\
\hline 20 & Дорога, яма & VIII-XIІвв. & муж. & $35-40$ \\
\hline 21 & Траншея слива орошения, п. 1 & VIII-X вв. & - & $12-13$ \\
\hline 22 & $\begin{array}{l}\text { Поселок Донецкий, насосная р. I, } \\
\text { п.1 }\end{array}$ & VIII-X вв. & жен. & $12-13$ \\
\hline 23 & Р. I, п.44 & VIII в. & - & $12-14$ мес. \\
\hline 24 & Маяки, 1990, p.I (пригород), Б-2-3 & VIII-X вв & жен & $35-40$ \\
\hline 25 & $\begin{array}{l}\text { Сокол-Кутиловский, } \\
\text { мог-к Райгородок }\end{array}$ & VIII-XI вв. & муж & $45-50$ \\
\hline 26 & ДИМ-А-69 кл.43567, погреб. тюрка & VIII в. & $-/ /-$ & $35-40$ \\
\hline 27 & $\begin{array}{l}\text { Екатеринославская губерния Ново- } \\
\text { московский уезд. Погребение хазара }\end{array}$ & VIII в. & $-/ /-$ & $30-35$ \\
\hline 28 & $\begin{array}{l}\text { Райгородок, меловой карьер, погр. } \\
\text { тюрка-кочевника }\end{array}$ & $?$ & муж. & $40-45$ \\
\hline 29 & $\begin{array}{l}\text { п.Першотравневое к.4, п.5, поло- } \\
\text { вецкое погребение }\end{array}$ & XII в. & $-/ /-$ & $20-25$ \\
\hline 30 & p.II (пригород), п.I & XV в. & $-/ /-$ & $17-19$ \\
\hline 31 & Р. II, (пригород, канава трубы) & 1812 г & муж & $20-25$ \\
\hline
\end{tabular}




\begin{tabular}{|c|c|c|c|c|c|c|c|c|c|c|c|c|c|c|c|}
\hline 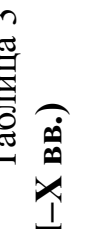 & 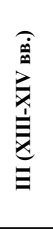 & $\therefore$ & - & + & 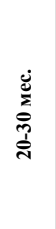 & & & & & & & & & & \\
\hline$\sum$ & \multicolumn{5}{|c|}{$\infty$} & $\vec{\sigma}$ & $\underset{i}{8}$ & $\stackrel{\mathscr{g}}{\sigma}$ & $\stackrel{\infty}{i}$ & $\underset{f}{\sharp}$ & 常 & $\begin{array}{l}\text { J } \\
\underset{f}{2}\end{array}$ & $\overrightarrow{\vec{i}}$ & $\underset{I}{F}$ & \\
\hline 岁 & \multicolumn{5}{|c|}{$\star$} & $\hat{\tilde{N}}$ & $\begin{array}{l}0 \\
\dot{\delta} \\
I\end{array}$ & 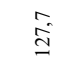 & $\stackrel{\overbrace{}}{\stackrel{\theta}{g}}$ & $\stackrel{n}{a}$ & $\frac{n}{d}$ & $\begin{array}{l}\stackrel{+}{I} \\
\stackrel{J}{J}\end{array}$ & $\begin{array}{c}\stackrel{m}{0} \\
\stackrel{0}{0}\end{array}$ & $\dot{a}$ & : \\
\hline$\pi$ & \multicolumn{5}{|c|}{$=$} & m & n & m & m & N & $N$ & N & m & N & - \\
\hline $\overrightarrow{3}$ & - & $\therefore$ & $\begin{array}{l}\dot{\dot{\dot{\leftrightarrow}}} \\
\dot{\dot{\varepsilon}}\end{array}$ & - & $\stackrel{m}{\Xi}$ & & & & & & & & & & \\
\hline$\sum_{0}^{\tilde{O}}$ & - & 栏 & 高 & & $\begin{array}{l}\text { 导 } \\
\text { 足 }\end{array}$ & & & & & & & & & & \\
\hline 宅 & - & $\stackrel{\bar{z}}{*}$ & & $\overrightarrow{\mathrm{g}}$ & 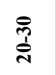 & & & & & & & & & & \\
\hline $\begin{array}{l}\frac{2}{v} \\
\frac{1}{z}\end{array}$ & - & $\therefore$ & 产 & $\sim$ & 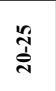 & & & & & & & & & & \\
\hline 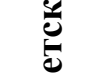 & - & $\stackrel{\bar{E}}{*}$ & & $\sigma$ & 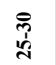 & & $\begin{array}{l}\circ \\
\dot{I}\end{array}$ & 롬 & $\begin{array}{l}\stackrel{\circ}{\circ} \\
\stackrel{0}{\Theta}\end{array}$ & $\stackrel{0}{\circ}$ & $\stackrel{0}{\circ}$ & ¿े & فํํㄹ & & \\
\hline 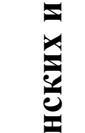 & 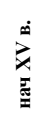 & 養 & 言 & - & 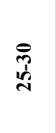 & & & & & & & & & & \\
\hline$\hat{x}$ & - & $\therefore$ & $=$ & $\sim$ & $\stackrel{7}{\stackrel{3}{\leftrightarrows}}$ & & & & & & & & & & \\
\hline 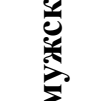 & - & $\frac{2}{2}$ & हू & - & 馬 & & & & & & & & & & \\
\hline$\stackrel{5}{S}$ & - & 栏 & & 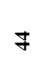 & 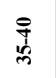 & $\stackrel{0}{\stackrel{0}{\infty}}$ & 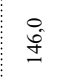 & $\stackrel{\circ}{\mathrm{m}}$ & $\stackrel{\stackrel{\Xi}{\Xi}}{=}$ & : & ๙ิ & $\stackrel{\circ}{\mathrm{I}}$ & ปे & $\stackrel{\ominus}{\stackrel{0}{\Xi}}$ & : \\
\hline 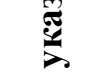 & - & $\stackrel{\bar{z}}{\bar{z}}$ & - & - & $\begin{array}{l}\text { đั่ } \\
\text { ते }\end{array}$ & & & & & & & & & & \\
\hline$\vec{a}$ & - & $\stackrel{\bar{E}}{\bar{*}}$ & & m & 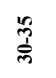 & & & & & & & & & & \\
\hline ले & & $\therefore$ & & $\sim$ & $\widehat{b}$ & & & & & & & & & & \\
\hline$\stackrel{D}{E}$ & & 美 & - & $\simeq$ & 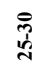 & $\stackrel{\circ}{ \pm}$ & 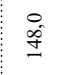 & $\begin{array}{l}\circ \\
\dot{0} \\
0\end{array}$ & $\stackrel{\circ}{\Xi}$ & & & & : & $\stackrel{\circ}{\stackrel{\circ}{\oplus}}$ & \\
\hline & 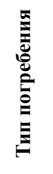 & $\stackrel{\bar{s}}{\Theta}$ & 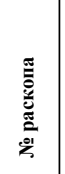 & 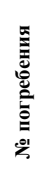 & 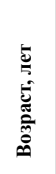 & 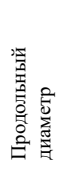 & 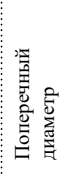 & 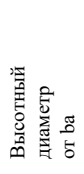 & 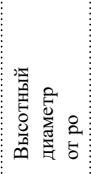 & 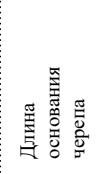 & 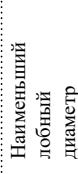 & 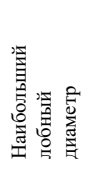 & 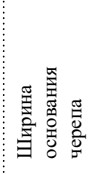 & 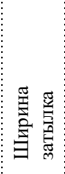 & 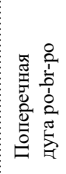 \\
\hline & & & & & & - & $\infty$ & $=$ & ¿ి & in & $\sigma$ & 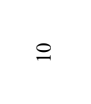 & $=$ & $\simeq$ & $\stackrel{\text { J }}{ }$ \\
\hline
\end{tabular}




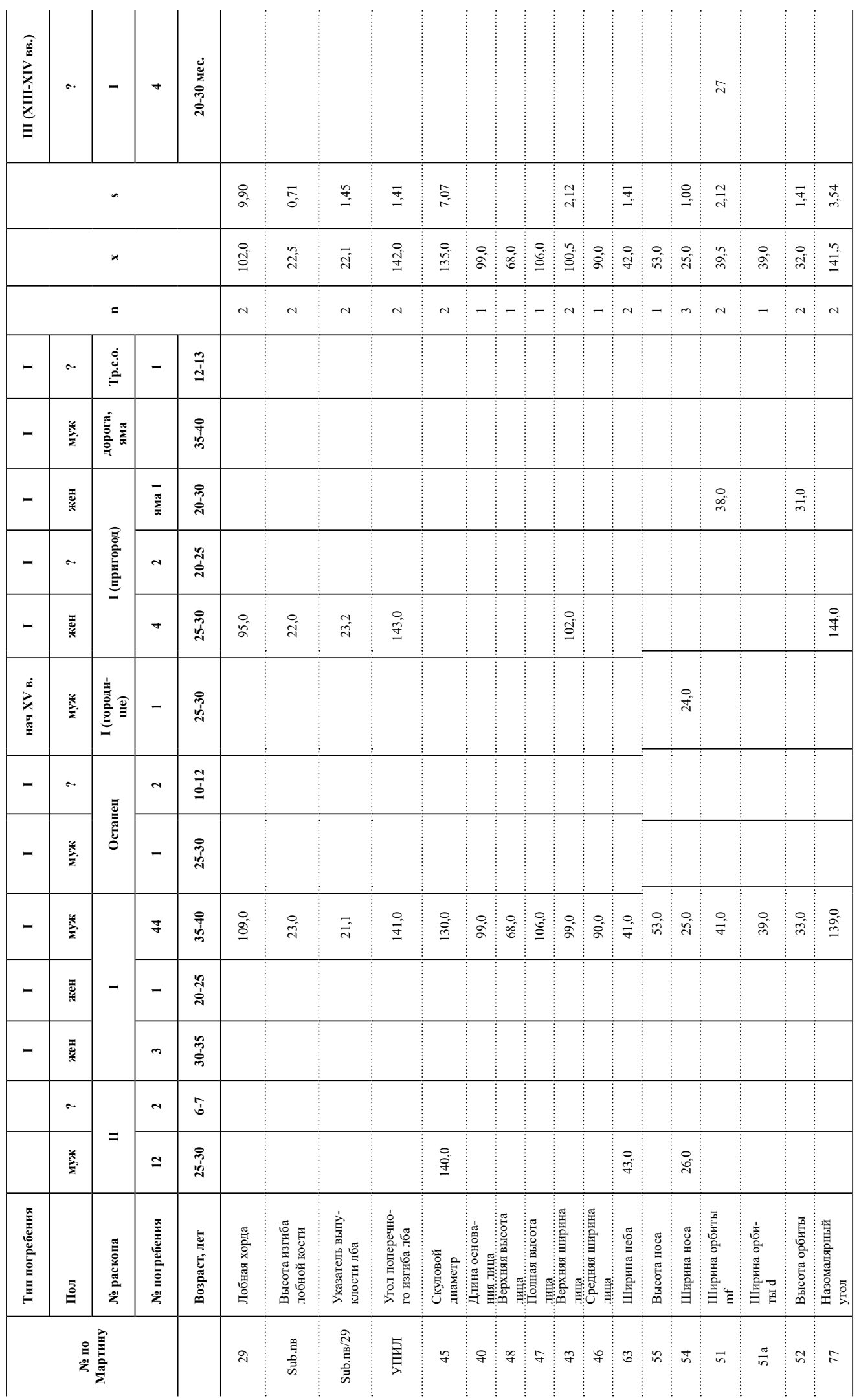




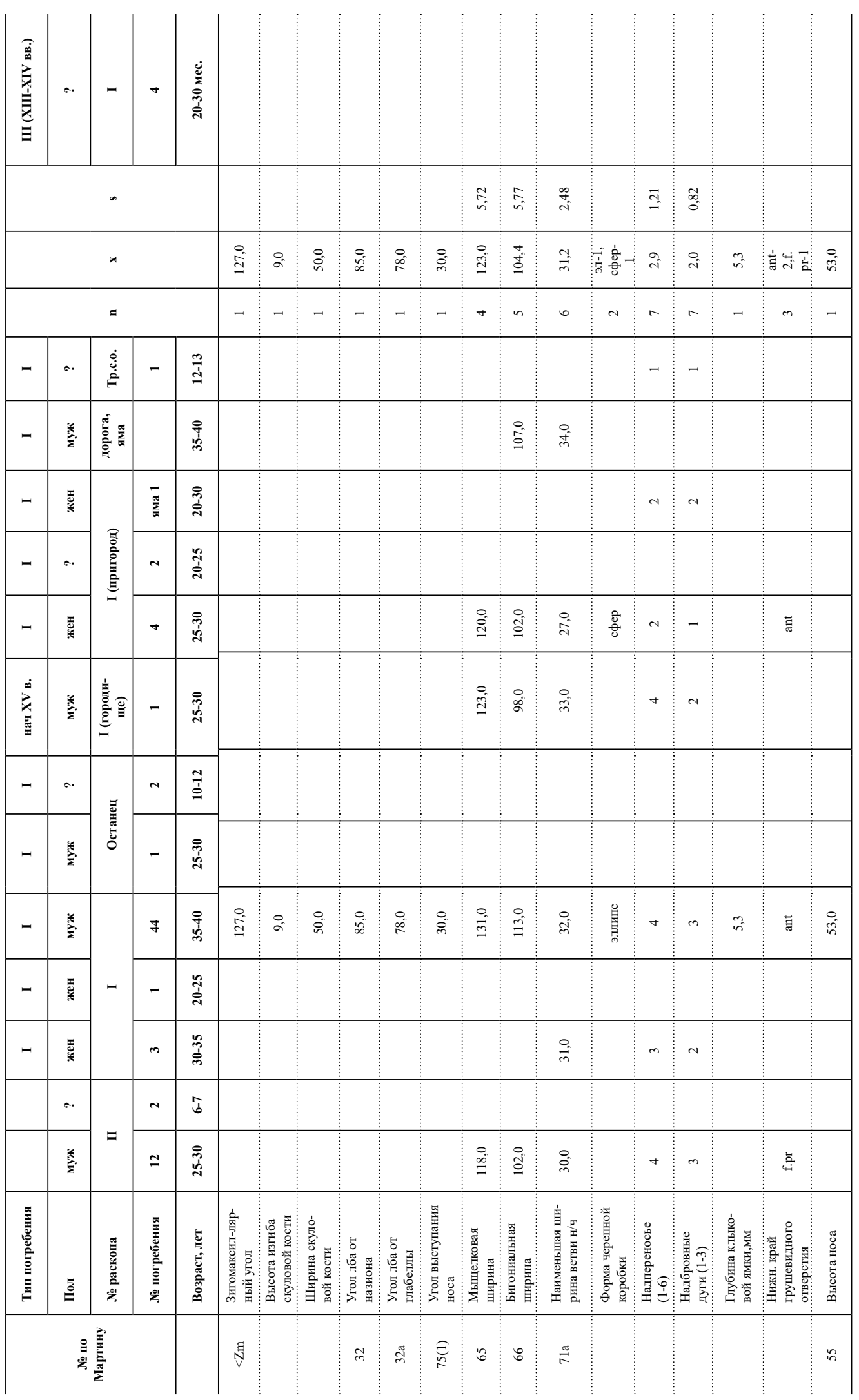




\begin{tabular}{|c|c|c|c|c|c|c|c|c|c|c|c|c|c|c|c|c|c|c|c|c|c|c|c|c|c|}
\hline 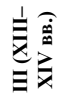 & a. & - & + & 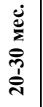 & & & & & & & & & & & & & & & & & & & & & \\
\hline & & . & & & $\stackrel{8}{-}$ & 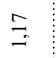 & $\stackrel{8}{0}$ & & & $\begin{array}{ll} \\
f^{2}\end{array}$ & $\stackrel{n}{n}$ & 会: & ले & 곡 & $\vec{b}$ & तु & & & & & $\frac{\infty}{m^{\prime}}$ & & 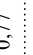 & & \\
\hline & & * & & & $i^{-1}$ & त' & $g$ & & & d) & $\overrightarrow{I f}$ & $\stackrel{+}{\stackrel{\infty}{\infty}:}$ & की & हे & $\begin{array}{l}2 \\
3\end{array}$ & $\begin{array}{l}\text { तै: } \\
\text { مू: }\end{array}$ & î: & $\frac{6}{0}$ & 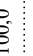 & $\vec{m}$ & $\frac{2}{d}$ & $\begin{array}{l}2 \\
\tilde{z}\end{array}$ & $\frac{1}{10}$ & $\begin{array}{l}0 \\
\dot{f} \\
\infty\end{array}$ & $\begin{array}{l}\infty^{\circ} \\
\infty^{2}\end{array}$ \\
\hline & & $=$ & & & $m$ & 0 & $a$ & - & & $m !$ & $m$ & $m$ & $\sim$ & N & $\sim$ & N & - & - & - & - & • & - & v & - & - \\
\hline - & a. & إن & - & 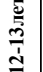 & & & - & & & & & & & & & & & & & & & & & & \\
\hline - & $\stackrel{2}{2}$ & 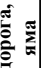 & & 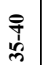 & & & & & & & & & & & & & & & & & & & & & \\
\hline- & 焉 & & $\overline{\tilde{z}}$ & 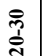 & & - & $\sim$ & & & & & & & & & & & & & & & & $\frac{0}{80}$ & & \\
\hline- & $\therefore$ & 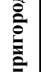 & $\sim$ & 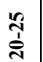 & & $m$ & $\sim$ & & & & & & & & & & & & & & & & & & \\
\hline - & 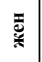 & & + & $\begin{array}{l}\text { क्रे } \\
\text { di }\end{array}$ & N & - & - & & & $\begin{array}{c}a^{2} \\
\infty \\
\infty\end{array}$ & 登 & f & $\bar{b}^{-}$ & in & $\stackrel{+}{\Delta}$ & 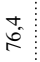 & & & & & $\begin{array}{l}0 \\
\infty \\
\infty\end{array}$ & & & & \\
\hline 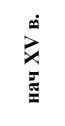 & 善 & 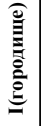 & - & $\begin{array}{l}\overrightarrow{7} \\
\text { d. }\end{array}$ & & & $N$ & & & & & & & & & & & & & & $\hat{i}$ & & & & \\
\hline - & $\therefore$ & $\bar{\Xi}$ & $\sim$ & $\frac{\pi}{3}$ & & & $N$ & & & & & & & & & & & & & & & & & & \\
\hline - & 美 & हू & - & 赵 & & & & & & & & & & & & & & & & & & & & & \\
\hline- & 坟 & & J & 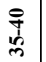 & $m$ & $\sim$ & $\sim$ & 。 & & 悹: & di & की & $\frac{\vec{b}}{6}$ & 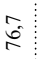 & (6) & : & mi: & $\frac{6}{6}$ & 8 & $\overrightarrow{\vec{n}}$ & $\begin{array}{l}? \\
\text { bे } \\
\infty\end{array}$ & $\begin{array}{l}\tilde{y} \\
\tilde{f}\end{array}$ & 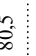 & $\begin{array}{l}\overbrace{\infty}^{\circ} \\
\text { if }\end{array}$ & $\begin{array}{l}\stackrel{0}{0} \\
\stackrel{\infty}{\infty}\end{array}$ \\
\hline - & $\underset{\tilde{F}}{\tilde{F}}$ & - & -1 & 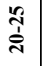 & & & & & & & & & & & & & & & & & & & & & \\
\hline - & 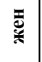 & & $m$ & 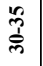 & & a & $\sim$ & & & & & & & & & & & & & & & & & & \\
\hline & a. & & N & $\hat{\jmath}$ & & & & & & & & & & & & & & & & & & & & & \\
\hline & 差 & & $\approx$ & 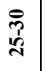 & $\sigma$ & 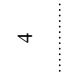 & $\mathrm{m}$ & & & $\begin{array}{ll}\overrightarrow{0} \\
\infty\end{array}$ & If & $\begin{array}{l}\infty \\
\infty \\
\infty \\
\infty\end{array}$ & & & & & & & & & 家 & & & & \\
\hline 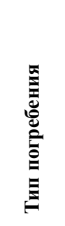 & $\stackrel{\bar{s}}{\Theta}$ & 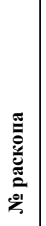 & 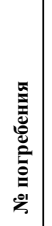 & 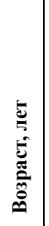 & 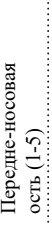 & 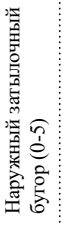 & 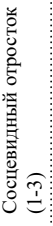 & 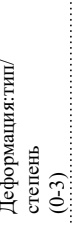 & 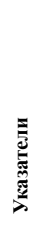 & : & 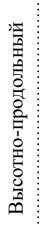 & 准 & 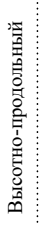 & 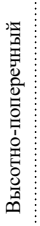 & 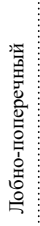 & 䈏: & 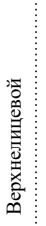 & 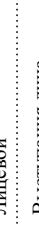 & & 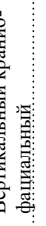 & & 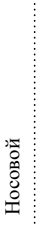 & 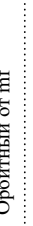 & 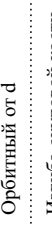 & 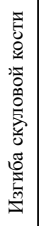 \\
\hline & 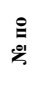 & 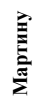 & & & & & & & & $\vec{\infty}_{0}$ & 프 & $\stackrel{\infty}{\Sigma}$ & 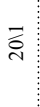 & $\stackrel{\infty}{\infty}:$ & $\frac{\infty}{\sigma}$ & 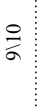 & 管 & ty & $\frac{b}{q}$ & 紊 & '0. & 炁 & th & $\begin{array}{l}\frac{\pi}{n} \\
\frac{\pi}{n}\end{array}$ & \\
\hline
\end{tabular}




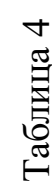

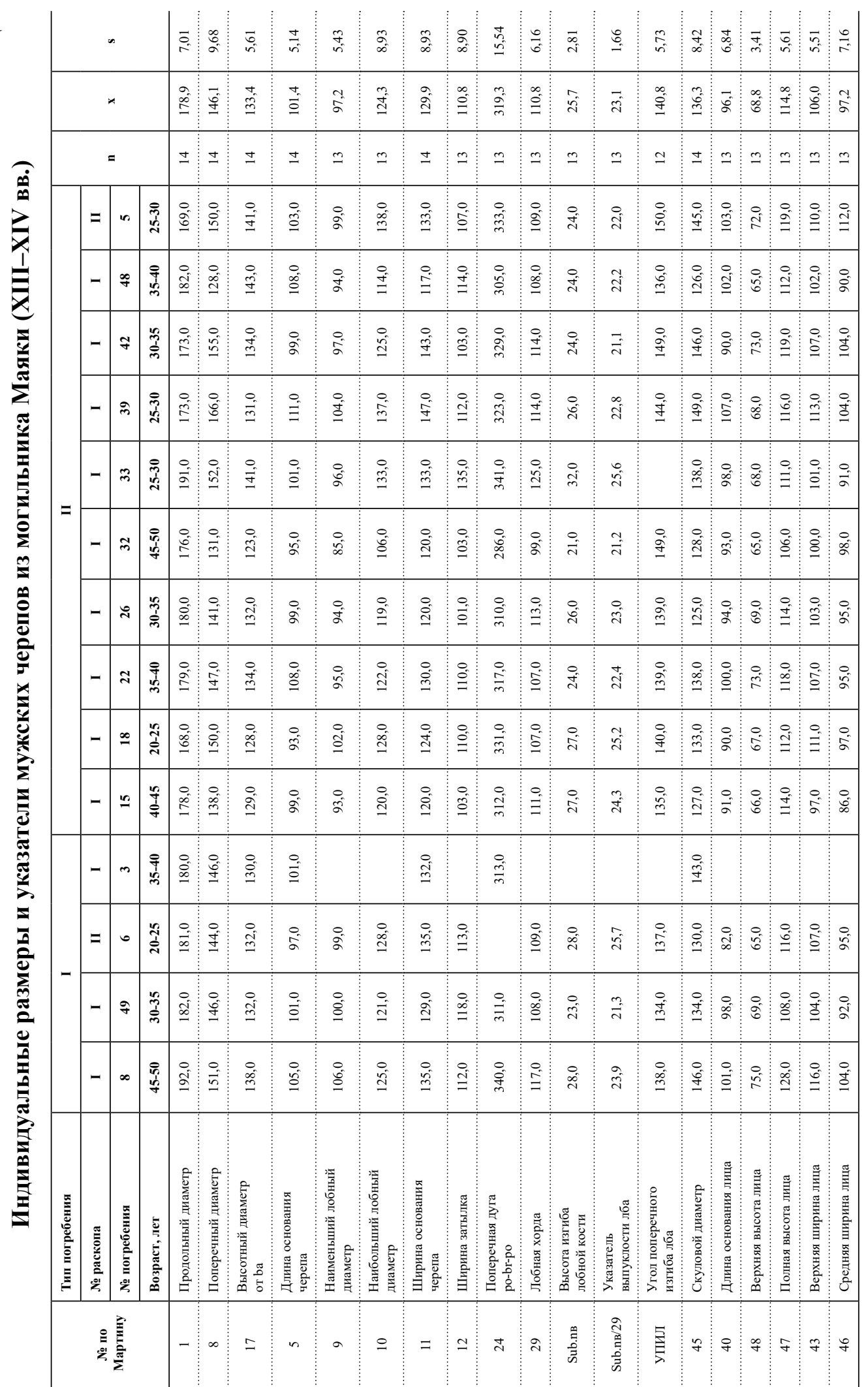




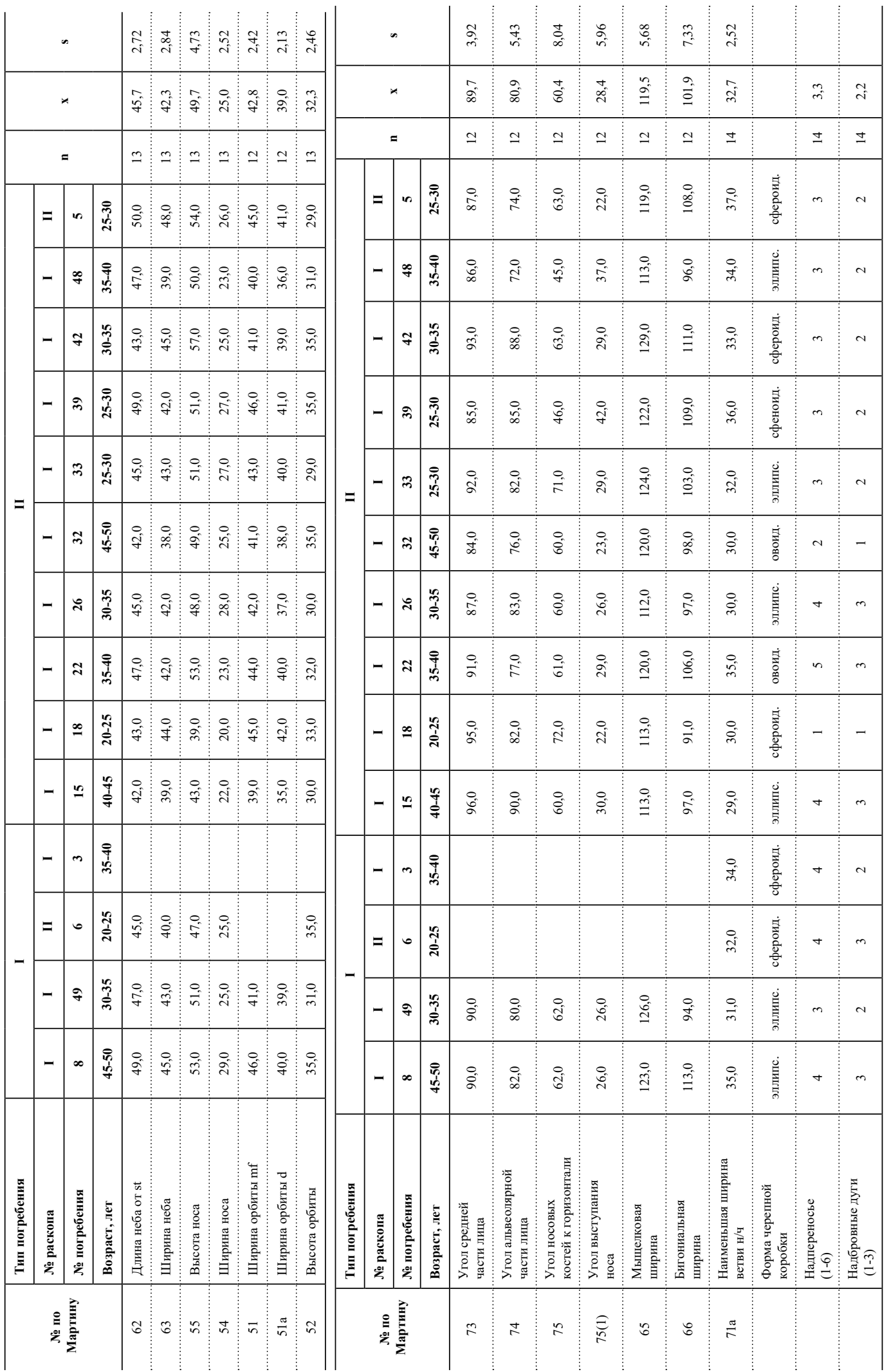




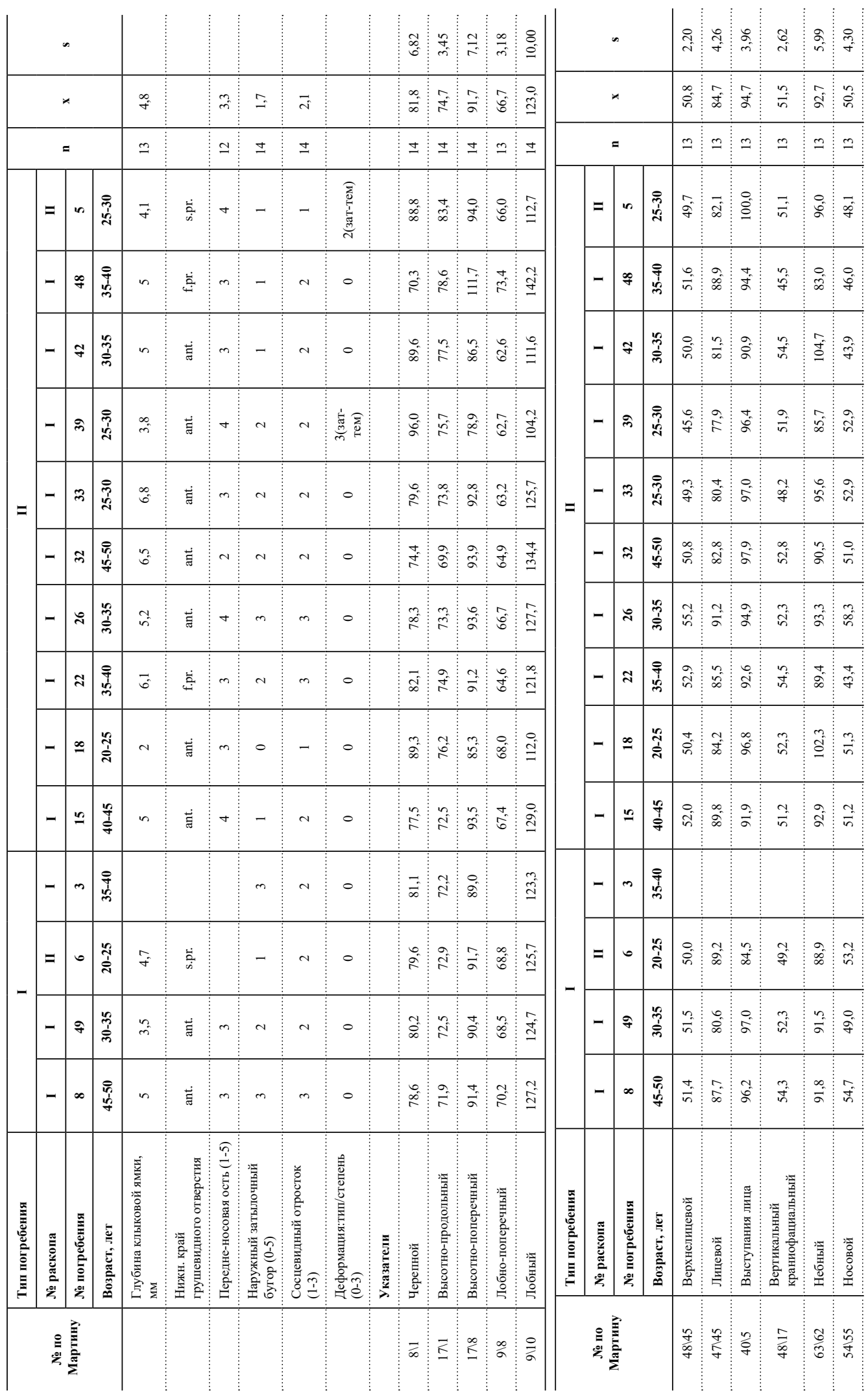




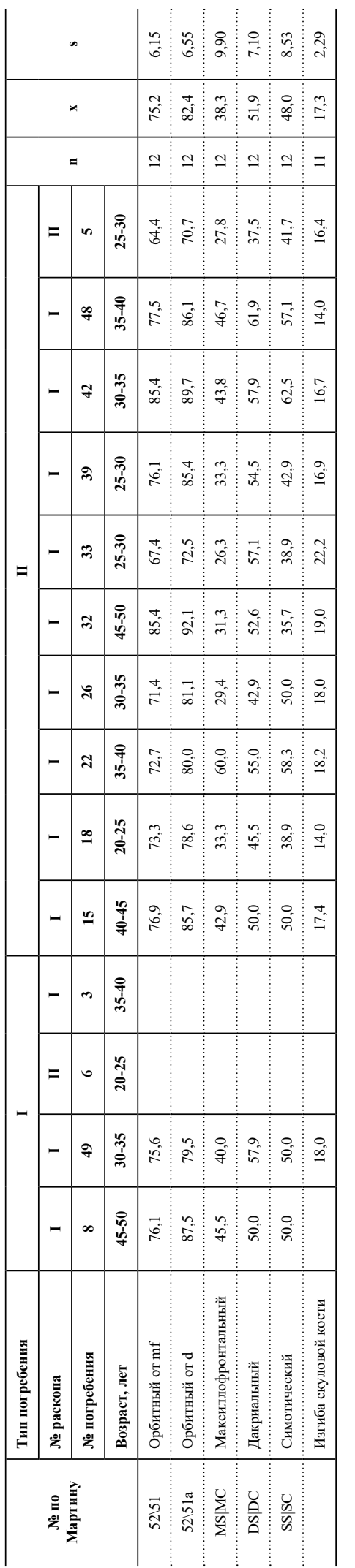

蓢

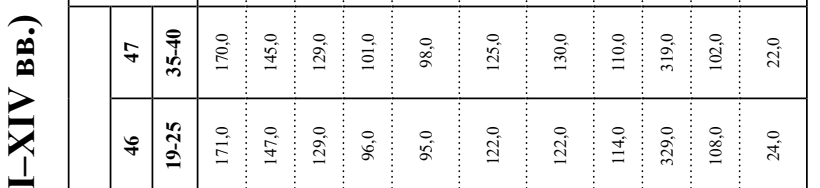

馬 三

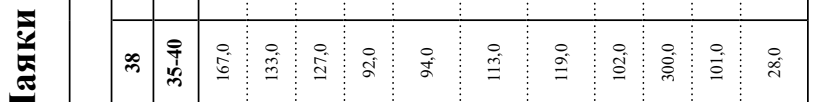

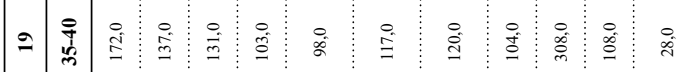

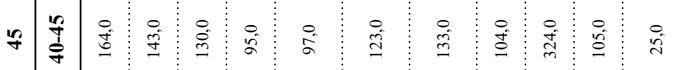

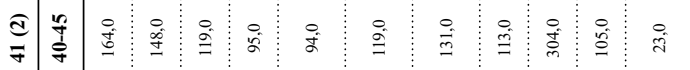

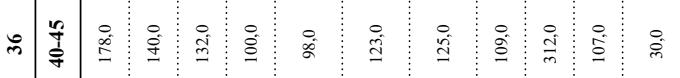

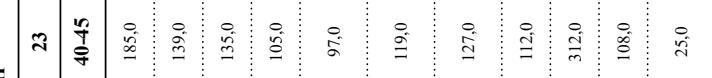

$=$

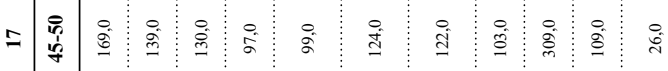

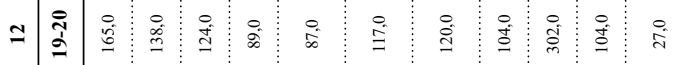

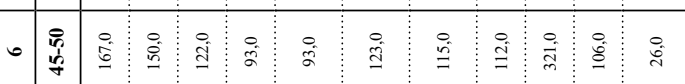

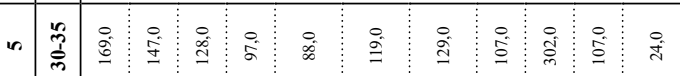

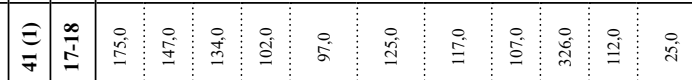

M

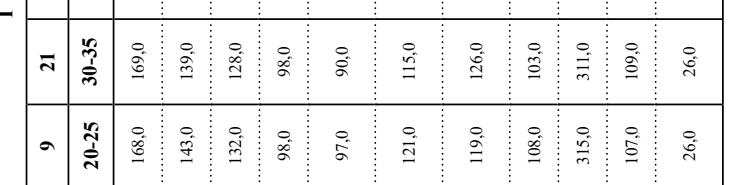

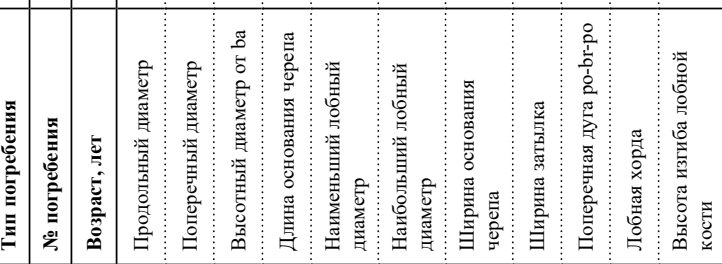

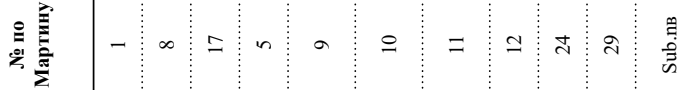




\begin{tabular}{|c|c|c|c|c|c|c|c|c|c|c|c|c|c|c|c|c|c|c|c|c|c|c|c|c|}
\hline \multicolumn{3}{|c|}{ n } & 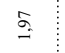 & $\underset{+}{\stackrel{8}{+}}$ & ले & $i_{i}$ & $\underset{\sim}{\infty}$ & $\stackrel{\infty}{\infty}$ & 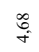 & $\frac{7}{n=7}$ & 売 & $\Rightarrow$ & $\frac{4}{4}$ & \multicolumn{2}{|r|}{$n$} & 告 & ${ }_{n}^{\infty}$ & $\underset{-\infty}{\infty}$ & $\approx$ & $\stackrel{\circ}{\circ}$ & : & हे & 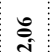 & in \\
\hline \multicolumn{3}{|c|}{ 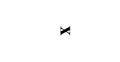 } & fี & 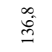 & 宅 & $\bar{\sigma}$ & $8^{2}$ & $\stackrel{\dddot{J}}{\Xi}$ & $\overline{\bar{\Delta}}$ & : & $\frac{7}{7}$ & d. & 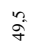 & \multicolumn{2}{|c|}{ * } & 竎 & $\vec{F}$ & $\infty$ & $\vec{g}$ & $\stackrel{m}{\stackrel{2}{2}}$ & هُ & 6 & $\ddot{2}$ & $\sigma$ \\
\hline \multicolumn{3}{|c|}{$=$} & $=$ & $=$ & $=$ & $=$ & $=$ & $=$ & $=$ & $=$ & $=$ & $=$ & $=$ & \multicolumn{2}{|r|}{$=$} & $=$ & $=$ & $=$ & $=$ & $=$ & $\simeq$ & 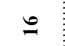 & $=$ & $=$ \\
\hline \multirow{5}{*}{$\equiv$} & F & 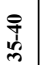 & $\stackrel{0}{i}$ & 主 & 兽 & d. & $\dot{\circ}^{\circ}$ & $\stackrel{\leftrightarrow}{\circ}$ & 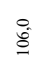 & $\sigma^{*}$ & $\stackrel{\circ}{\circ}$ & $\underset{+}{+}$ & कि. & \multirow{2}{*}{$\Xi$} & $f \underset{c}{q}$ & ì & : & 品 & o & 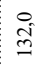 & $\stackrel{\circ}{\stackrel{0}{0}}$ & 8 & ì & $\therefore$ \\
\hline & $\%$ & สิ & สี & $\begin{array}{l}0 \\
\stackrel{8}{\circ}\end{array}$ & & 80 & $\dot{\mathrm{b}}$ & $\stackrel{\circ}{\circ}$ & 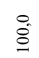 & $\ddot{\infty}$ & 8 & 冓 & 嵩 & \multirow{3}{*}{ 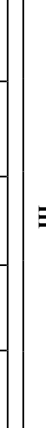 } & 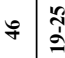 & id & $\stackrel{\circ}{f}$ & $\stackrel{\circ}{\circ}$ & $\begin{array}{l}0 \\
\text { in } \\
\text { a }\end{array}$ & $\begin{array}{c}0 \\
\stackrel{8}{a} \\
\end{array}$ & $\stackrel{\circ}{\therefore}$ & 8 & :े & $\therefore$ \\
\hline & q & $\begin{array}{l}P \\
⿱ f \\
d \\
d\end{array}$ & $\overrightarrow{\text { iे }}$ & $\stackrel{8}{\dot{q}}$ & İ & 8 & $\circ$ & 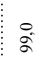 & $\ddot{\infty}$ & $\stackrel{8}{\circ}$ & वे & $\infty$ & 品 & & F & $\begin{array}{c}0 \\
\text { id } \\
\text { a }\end{array}$ & $\stackrel{\circ}{\dot{q}}$ & $\frac{0}{m}$ & 家 & $\frac{i}{9}$ & O & \& & $\ddot{1}$ & $\stackrel{\circ}{\therefore}$ \\
\hline & $\infty$ & 早 & $\overline{\mathrm{i}}$ & 恿 & 용 & 8 & id & $\stackrel{8}{\circ}$ & $\stackrel{\Xi}{\doteq}$ & $\stackrel{8}{\circ}$ & f & $\stackrel{\circ}{\dot{q}}$ & 字 & & $\infty \underset{ల}{\infty}$ & $\stackrel{i}{i}$ & $\stackrel{\circ}{\circ}$ & 品 & $\dot{0}$ & $\frac{\overrightarrow{0}}{m}$ & $\stackrel{\circ}{\stackrel{0}{9}}$ & $0^{\circ}$ & $\stackrel{\circ}{\circ}$ & $\infty$ \\
\hline & 2 & 导 & छे & $\begin{array}{l}\circ \\
\text { d. }\end{array}$ & 竎 & 8 & 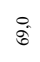 & $\stackrel{\circ}{=}$ & $\stackrel{\circ}{\circ}$ & i & 감 & $\stackrel{\circ}{\circ}$ & $\stackrel{8}{\circ}$ & & $=9$ & i. & 감 & 票 & : & 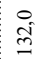 & $\stackrel{\circ}{\check{I}}$ & $\therefore$ & de & $\stackrel{\circ}{=}$ \\
\hline \multirow{8}{*}{ 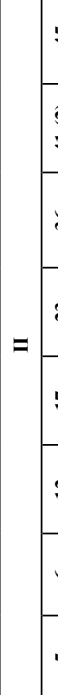 } & if & $\frac{1}{8}$ & $\underset{\sim}{\infty}$ & 郘 & ذِ & 80 & $\stackrel{8}{8}$ & $\stackrel{ }{\mathrm{d}}$ & $\dot{8}$ & $\stackrel{\circ}{\infty}$ & $\stackrel{\circ}{\mathrm{j}}$ & $\stackrel{\dot{q}}{\mathrm{~g}}$ & స్ & & if $\frac{4}{f}$ & id & fo & 通 & 过 & $\frac{0}{9}$ & $\stackrel{\circ}{2}$ & $\therefore$ & dำ & $\stackrel{0}{\circ}$ \\
\hline & $\mid \begin{array}{l}\widehat{a} \\
\overline{7}\end{array}$ & $\frac{10}{\dot{q}}$ & $\overrightarrow{\vec{त}}$ & 寺 & 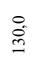 & 8 & $\stackrel{\circ}{\circ}$ & $\stackrel{\stackrel{\oplus}{ \pm}}{=}$ & $\stackrel{0}{\stackrel{8}{0}}$ & $0^{\circ}$ & 워 & $\underset{+}{\stackrel{f}{F}}$ & 守 & & 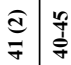 & $\begin{array}{l}0 \\
\text { d } \\
\text { d }\end{array}$ & $\stackrel{\circ}{\circ}$ & $\frac{0}{m}$ & $\begin{array}{c}0 \\
i \\
\end{array}$ & $\stackrel{\circ}{\stackrel{0}{2}}$ & $\stackrel{\circ}{\check{0}}$ & $\stackrel{\circ}{+}$ & 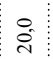 & $\infty$ \\
\hline & i & $\frac{2}{8}$ & 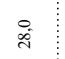 & 总 & 递 & 8 & 8 & $\stackrel{\circ}{\oplus}$ & dำ & $\infty$ & $\stackrel{\vec{j}}{\mathrm{j}}$ & मे & $\stackrel{8}{\circ}$ & & $\begin{array}{lll}0 \\
0\end{array}$ & id & 守 & o. & : & $\begin{array}{c}0 \\
\text { did }\end{array}$ & $\stackrel{\circ}{=}$ & : & $\ddot{2}$ & I \\
\hline & $\approx$ & $\frac{d}{\dot{d}}$ & $\overrightarrow{\mathrm{a}}$ & $\stackrel{\stackrel{\vec{I}}{I}}{ }$ & 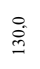 & $\stackrel{8}{\stackrel{8}{\theta}}$ & $\stackrel{8}{\circ}$ & $\stackrel{\ominus}{\stackrel{\dot{\theta}}{9}}$ & $\stackrel{\circ}{\stackrel{0}{0}}$ & \&్ & 过 & $\stackrel{+}{\dot{a}}$ & $\stackrel{\circ}{\dot{q}}$ & & $\approx \frac{i f}{f}$ & id & $\mid$ & $\begin{array}{l}0 \\
\text { f }\end{array}$ & 总 & $\begin{array}{l}\stackrel{0}{2} \\
\text { న్ }\end{array}$ & $\stackrel{\vec{a}}{\vec{a}}$ & $\stackrel{\circ}{\therefore}$ & did & $\stackrel{\circ}{\circ}$ \\
\hline & $=$ & $\begin{array}{l}8 \\
\text { in } \\
\text { s. }\end{array}$ & ते & 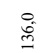 & d̊ & $\stackrel{\circ}{\infty}$ & : & $\stackrel{\circ}{\leftrightarrows}$ & $\stackrel{8}{8}$ & $\stackrel{8}{+0}$ & 高 & ले & iे & & $=\begin{array}{l}8 \\
b \\
6\end{array}$ & $\frac{0}{i}$ & fi & $\begin{array}{c}0 \\
\text { in } \\
m\end{array}$ & $\begin{array}{l}0 \\
\infty \\
\end{array}$ & $\stackrel{0}{I}$ & $\stackrel{\text { i }}{0}$ & $\therefore$ & in & $\stackrel{\circ}{\because}$ \\
\hline & $\simeq$ & สิ & $\stackrel{0}{\circ}$ & $\stackrel{\circ}{\dot{q}}$ & ذ্. & 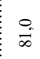 & if & $\stackrel{\circ}{\stackrel{\circ}{\circ}}$ & 80 & $\stackrel{\dot{\Phi}}{\dot{\infty}}$ & $\infty$ & 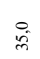 & : & & 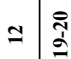 & ij & $\mid \begin{array}{l}0 \\
\infty \\
\infty \\
m\end{array}$ & $\begin{array}{c}0 \\
m \\
m\end{array}$ & $\frac{8}{9}$ & 定 & $\stackrel{\circ}{\stackrel{i}{g}}$ & in & 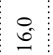 & 8 \\
\hline & 0 & $\begin{array}{l}8 \\
\text { is } \\
\text { s. }\end{array}$ & za & 昜 & đ্ & 8 & 8 & 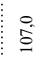 & $\stackrel{\circ}{\dot{ \pm}}$ & ij & : & 守 & : & & \begin{tabular}{lll}
0 & \multicolumn{1}{c}{} \\
4 & 8
\end{tabular} & id & $\stackrel{\circ}{f}$ & 遖 & I & $\stackrel{\circ}{\stackrel{\Xi}{\beth}}$ & $\stackrel{0}{\stackrel{2}{2}}$ & 8 & : & $\therefore$ \\
\hline & in & है & đ̇ं & $\stackrel{\circ}{\dot{I}}$ & 范 & 8 & $\stackrel{\circ}{r}$ & $\stackrel{\stackrel{\rho}{\prime}}{=}$ & 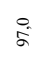 & $\stackrel{0}{\circ}$ & $\stackrel{8}{\dot{q}}$ & $\stackrel{\circ}{\vec{f}}$ & त्रे & & n & ij & 암 & 宓 & $\frac{8}{ \pm}$ & $\stackrel{\circ}{\mathrm{I}}$ & $\stackrel{\circ}{\stackrel{0}{0}}$ & $\therefore$ & $\stackrel{2}{\circ}$ & $\because$ \\
\hline & $\begin{array}{l}\Xi \\
\overline{7}\end{array}$ & $\stackrel{\infty}{I}$ & $\vec{\lambda}$ & స్త్ర & هิำ & 80 & $\dot{8}$ & $\stackrel{\infty}{=}$ & $\stackrel{\circ}{\circ}$ & ì & 字 & $\stackrel{\circ}{\dot{a}}$ & 官 & & 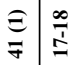 & $\begin{array}{l}0 \\
\text { in }\end{array}$ & F & oi & $\begin{array}{l}0 \\
0 \\
0 \\
\end{array}$ & $\begin{array}{c}0 \\
\stackrel{0}{0}\end{array}$ & $\stackrel{\therefore}{\Xi}$ & 0 & id & $\circ$ \\
\hline & $\mathscr{A}$ & $\begin{array}{l}n \\
\tilde{m} \\
\tilde{m}\end{array}$ & i. & 吕 & 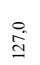 & $\infty$ & 8 & $\stackrel{\circ}{\stackrel{B}{B}}$ & $\stackrel{\circ}{2}$ & ले & 过 & ষे & 守 & & 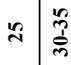 & is & $\stackrel{\circ}{\circ}$ & 品 & o & $\begin{array}{l}0 \\
\text { 仿 }\end{array}$ & & & 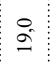 & $\therefore$ \\
\hline & $\bar{\pi}$ & $\begin{array}{l}\mathscr{m} \\
\tilde{e}\end{array}$ & ने & 总 & 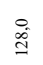 & $\infty$ & 8 & $\stackrel{\infty}{=}$ & $\stackrel{\circ}{ \pm}$ & ฌু & $\stackrel{\circ}{\stackrel{\circ}{+}}$ & 求 & iี & & $\bar{\nabla}$ & 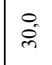 & $\stackrel{\circ}{\circ}$ & 㤩 & $\begin{array}{l}0 \\
0 \\
\\
-1\end{array}$ & $\begin{array}{l}0 \\
0 \\
0\end{array}$ & $\stackrel{\circ}{a}$ & 8 & $\frac{0}{\vec{d}}$ & $\circ$ \\
\hline & a & $\begin{array}{l}\text { సิ } \\
\text { ஸे }\end{array}$ & $\frac{7}{d}$ & $\stackrel{尺}{\stackrel{8}{g}}$ & $\stackrel{\circ}{\mathrm{I}}$ & 8 & 8 & $\stackrel{\circ}{\circ}$ & 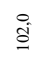 & $\dot{\infty}$ & 字 & i & 宛 & & $\sigma \mid$\begin{tabular}{l}
$n$ \\
\multirow{d}{N}{}
\end{tabular} & ì & F & 品 & $\stackrel{\circ}{\circ}$ & $\stackrel{8}{8}$ & ¿ें & $\begin{array}{l}0 \\
\infty\end{array}$ & $\frac{0}{\lambda}$ & $\stackrel{\circ}{\circ}$ \\
\hline \multicolumn{2}{|c|}{ 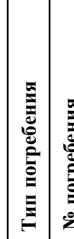 } & 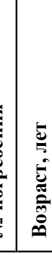 & $\begin{array}{l}\text { हू } \\
0 \\
0\end{array}$ & 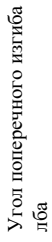 & 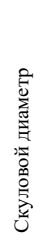 & 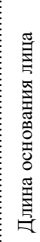 & 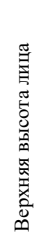 & 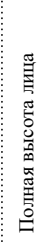 & 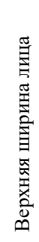 & 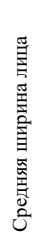 & 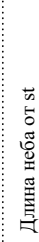 & 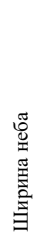 & 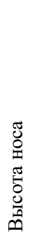 & 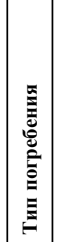 & 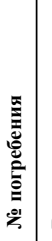 & 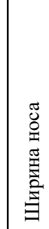 & 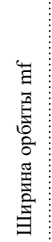 & 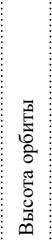 & 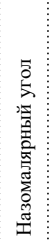 & 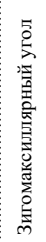 & 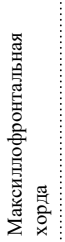 & 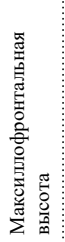 & 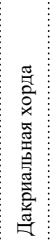 & 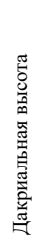 \\
\hline & 焉 & & 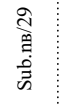 & 貝 & 8 & q & $\stackrel{\infty}{q}$ & F & q & f & ช & 8 & in & & 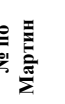 & 品 & $\vec{n}$ & $\approx$ & $\therefore$ & ปี & $\bar{\Sigma}$ & $\sum_{\Sigma}^{n}$ & $\mathscr{a}$ & $a$ \\
\hline
\end{tabular}




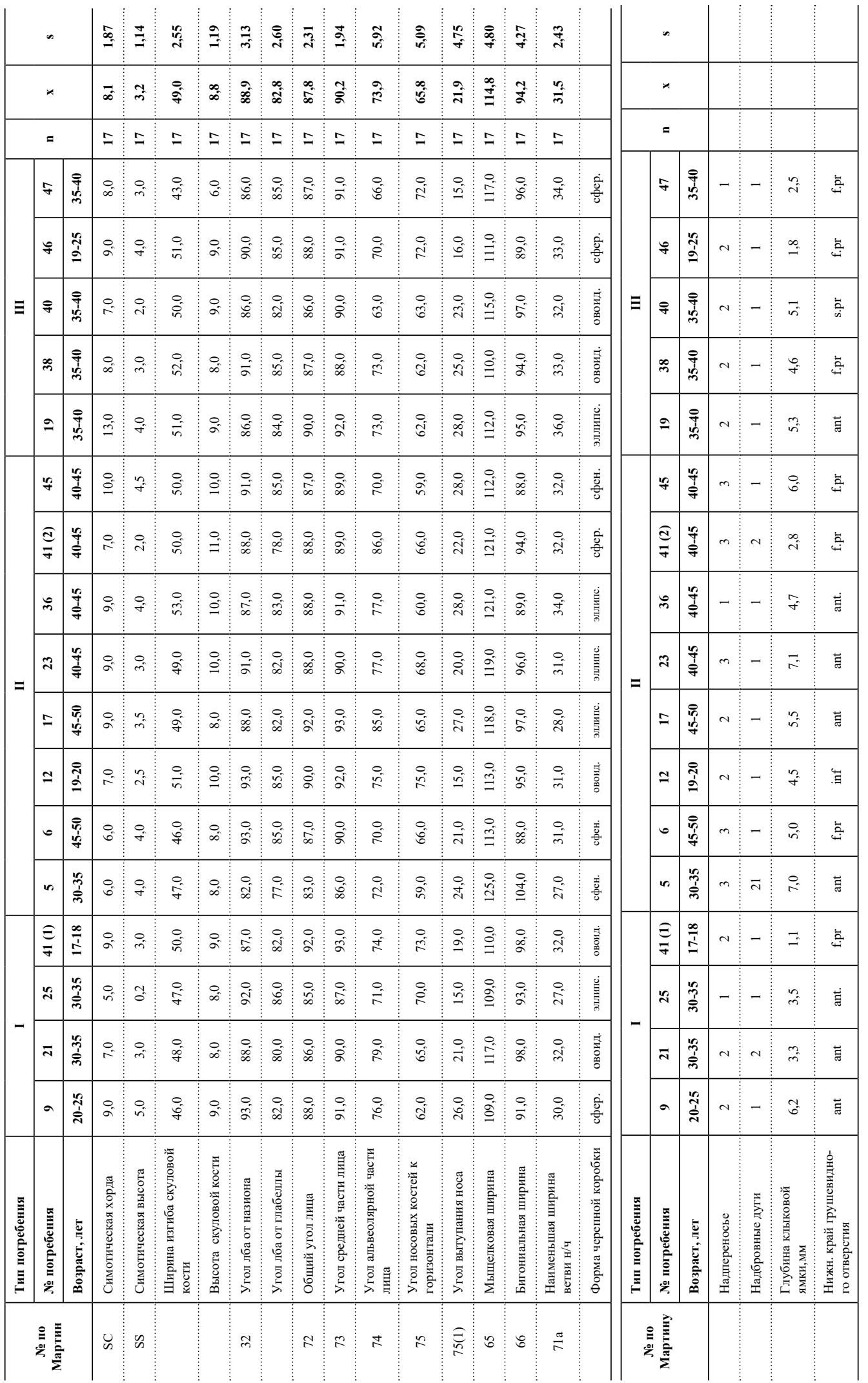




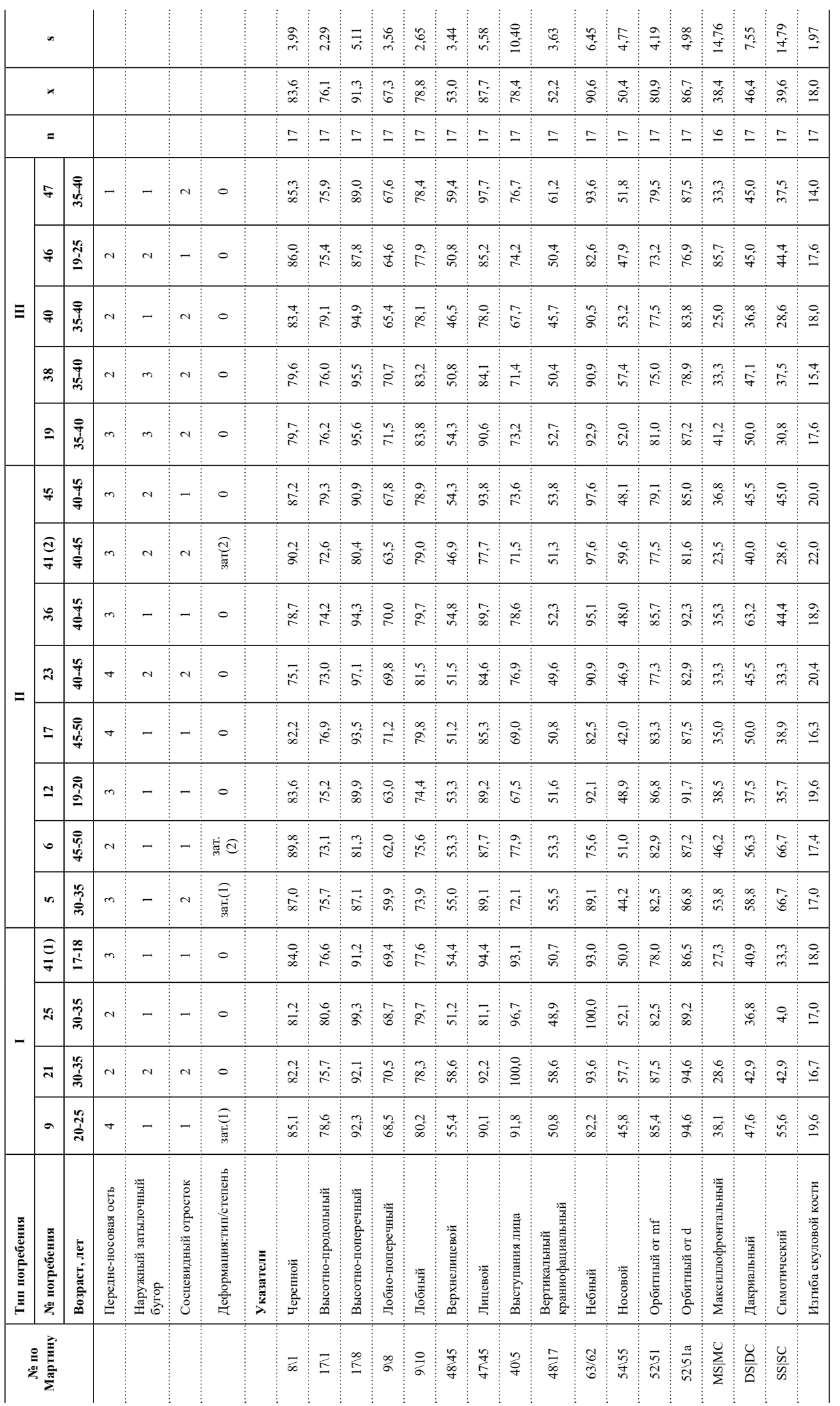




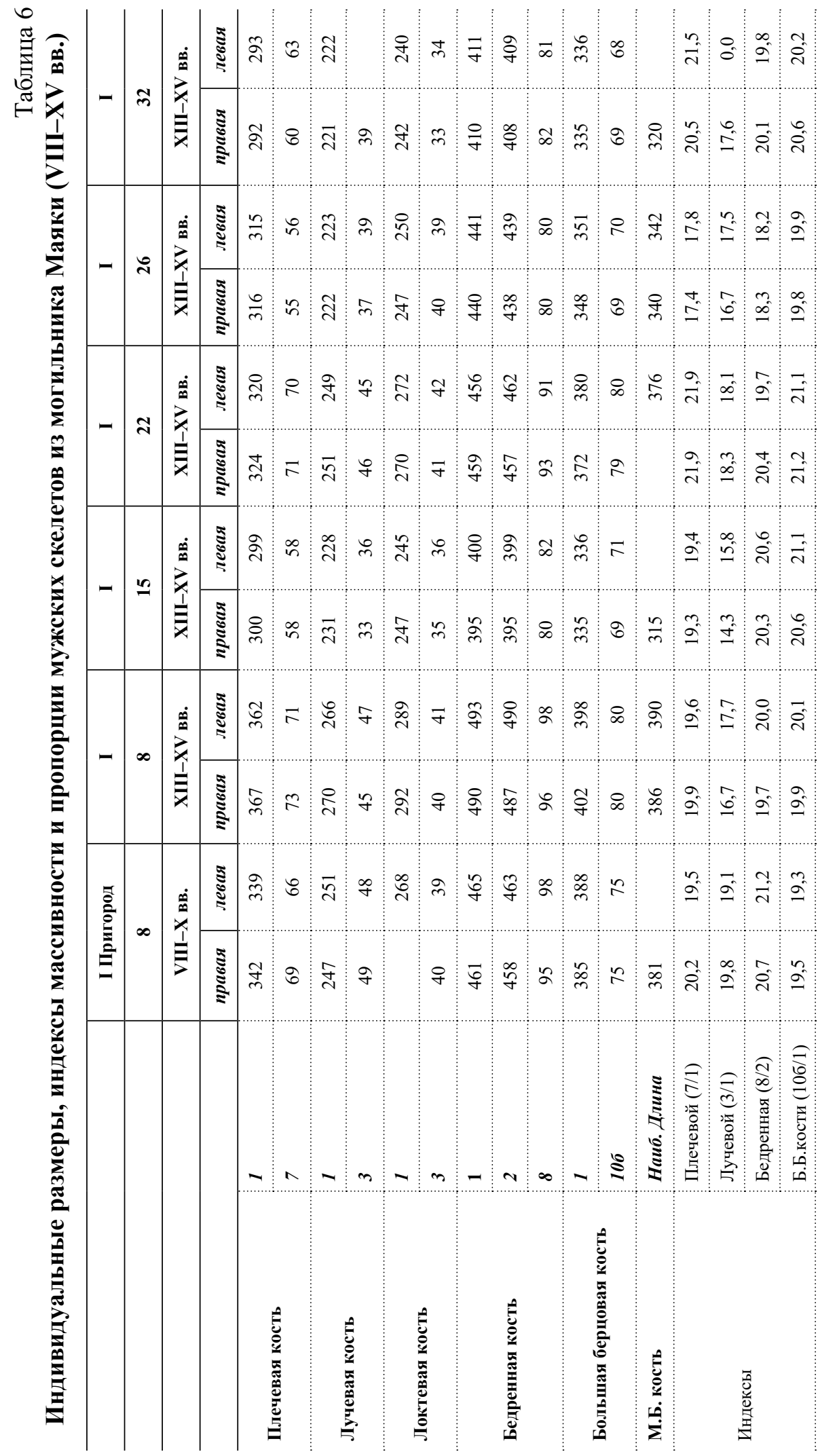




\begin{tabular}{|c|c|c|c|c|c|c|c|c|c|c|c|c|c|c|c|c|c|c|c|c|}
\hline \multirow{2}{*}{-} & \multirow{2}{*}{ లె } & \multirow{2}{*}{ 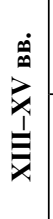 } & \multirow{2}{*}{ 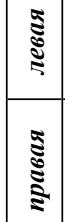 } & $\stackrel{0}{i}$ & $\overrightarrow{\mathbb{b}^{\prime}}$ & $\begin{array}{l}\infty \\
\stackrel{n}{n}\end{array}$ & $\begin{array}{l}\tilde{N} \\
\tilde{\infty}\end{array}$ & \multirow{2}{*}{$\begin{array}{l}\hat{\infty} \\
\stackrel{0}{n}\end{array}$} & \multirow{2}{*}{$=$} & \multirow{2}{*}{ in } & \multirow{2}{*}{ 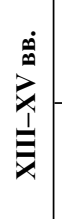 } & $\begin{array}{l}5 \\
\text { కัँ } \\
\end{array}$ & $\vec{m}$ & 8 & \multicolumn{2}{|c|}{ q } & ले & $\stackrel{g}{+}$ & \multicolumn{2}{|c|}{ f $\infty$} \\
\hline & & & & $\mid \begin{array}{l}0 \\
i\end{array}$ & $\begin{array}{l}0 \\
0 \\
0\end{array}$ & $\stackrel{n}{n}$ & $\overrightarrow{\tilde{\infty}}$ & & & & & $\begin{array}{l}\mathbf{Z} \\
\mathbb{Z} \\
\mathbb{\Xi}\end{array}$ & m) & t & q & $\stackrel{\infty}{\sim}$ & $\infty$ & 年 & $\vec{F}$ & $\infty$ \\
\hline \multirow{2}{*}{-} & \multirow{2}{*}{$\stackrel{i}{\circ}$} & $\dot{\ddot{\Theta}}$ & 胥 & $\begin{array}{l}\infty \\
\stackrel{R}{R}\end{array}$ & $\hat{\sigma}$ & $\stackrel{\infty}{\varrho^{\prime}}$ & $\begin{array}{l}0 \\
\dot{\infty}\end{array}$ & \multirow{2}{*}{$\begin{array}{c}m \\
\hat{\beta}\end{array}$} & \multirow{2}{*}{-} & \multirow{2}{*}{$\hat{q}$} & \multirow{2}{*}{ 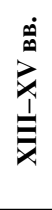 } & 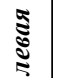 & వ্ల & 8 & त̃ f & $\vec{n}$ & $\approx$ & $\stackrel{\mathscr{f}}{\mathscr{\gamma}}$ & $\dddot{\approx}$ & $\infty$ \\
\hline & & $\stackrel{1}{\bar{x}}$ & 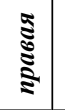 & $\overrightarrow{\mathfrak{i}}$ & $\begin{array}{l}\infty \\
\hat{b}\end{array}$ & $\stackrel{m}{R}$ & $\begin{array}{l}n \\
a^{2}\end{array}$ & & & & & 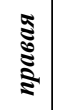 & ஓి & 8 & $\tilde{\tilde{n}} f$ & กิ & $m$ & $\stackrel{\mathscr{f}}{\mathscr{\gamma}}$ & $\stackrel{+}{\stackrel{+}{f}}$ & $\bar{\infty}$ \\
\hline \multirow{2}{*}{-} & \multirow{2}{*}{$\tilde{N}$} & $\dot{\ddot{\ddot{B}}}$ & 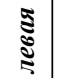 & $\hat{o}^{2}$ & $\begin{array}{c}n \\
6\end{array}$ & $\stackrel{\infty}{\curvearrowright}$ & $\underset{\infty}{\tilde{N}}$ & \multirow{2}{*}{$\begin{array}{l}0 \\
\dot{0}\end{array}$} & \multirow{2}{*}{-} & \multirow{2}{*}{$\stackrel{\infty}{+}$} & \multirow{2}{*}{ 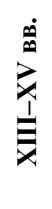 } & 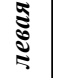 & $\stackrel{\simeq}{m}$ & to & $\stackrel{+}{\sim}$ F & $\mathbb{N}^{t}$ & के & $\stackrel{\infty}{\mathscr{\gamma}}$ & $\stackrel{\mathscr{Y}}{\mathscr{f}}$ & $\hat{a}$ \\
\hline & & $\stackrel{1}{\bar{x}}$ & $\begin{array}{l}\text { s. } \\
\text { ș } \\
\text { s. }\end{array}$ & $\hat{\imath}$ & $\begin{array}{l}n \\
5 \\
6\end{array}$ & $\stackrel{2}{\sim}$ & $\stackrel{+}{\infty}$ & & & & & 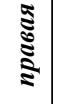 & $\frac{0}{m}$ & 8 & $\stackrel{n}{+}$ & $\overrightarrow{\mathrm{N}}$ & के & $\widehat{\vartheta}$ & $\tilde{F}$ & n \\
\hline & & 总 & ปัँ & $\begin{array}{l}\hat{I}^{\prime} \\
\text { to }\end{array}$ & $\stackrel{\circ}{6}$ & $\begin{array}{l}n \\
\hat{n}\end{array}$ & \begin{tabular}{l}
$\stackrel{1}{+}$ \\
\multirow{\infty}{\infty}{}
\end{tabular} & 0 & & & $\dot{\ddot{\oplus}}$ & 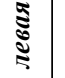 & $\vec{\sim}$ & to & $\vec{\sim}$ & $\stackrel{\tilde{n}}{\sim}$ & $F$ & $\stackrel{\infty}{\mp}$ & $\stackrel{\sim}{f}$ & $\tilde{\alpha}$ \\
\hline & & $\bar{x}$ & 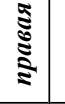 & in & $\stackrel{0}{0}$ & $\stackrel{0}{\stackrel{2}{\Omega}}$ & $\begin{array}{l}\infty \\
+ \\
\infty\end{array}$ & & & & $\bar{\nabla}$ & $\begin{array}{l}\mathbf{s} \\
\mathbb{\Xi} \\
\mathbf{\Xi}\end{array}$ & $\bar{m}$ & 8 & సి f & in: & F & $\vec{q}$ & ఫे & $\alpha$ \\
\hline & & 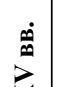 & 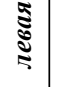 & $\hat{\imath}$ & $\begin{array}{l}\infty \\
0 \\
0\end{array}$ & $\begin{array}{l}n \\
\stackrel{n}{n}\end{array}$ & $\frac{1}{\infty}$ & $\sigma_{0}$ & & & $\dot{\ddot{m}}$ & 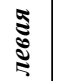 & $\stackrel{\vec{m}}{m}$ & $R \approx$ & 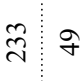 & $\stackrel{n}{n}$ & $F$ & $\stackrel{+}{\sigma}$ & $\ddot{q}$ & $\vec{\sigma}$ \\
\hline & & $\bar{x}$ & $\begin{array}{l}\text { s. } \\
\text { ș } \\
\text { s. }\end{array}$ & í & $\frac{2}{6}$ & $\stackrel{\infty}{\stackrel{2}{n}}$ & $\begin{array}{l}n \\
\tilde{\infty} \\
\infty\end{array}$ & - & & & $\bar{X}$ & $\begin{array}{l}\mathbf{z} \\
\mathbb{3} \\
\mathbf{s}\end{array}$ & 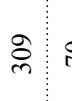 & $\stackrel{a}{\circ}$ & $\stackrel{\infty}{\mathbb{N}}$ f & 究 & ร & $\tilde{F}$ & $\bar{y}$ & $\tilde{a}$ \\
\hline ఫิ & & $\dot{\theta}$ & 气ั้ & $\begin{array}{l}\sim \\
\tilde{n}\end{array}$ & fं & $\begin{array}{l}0 \\
+\end{array}$ & $\stackrel{\infty}{\infty}$ & & & & 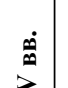 & 气ัँ & ते & 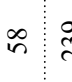 & సે ભે & $\stackrel{\infty}{n}^{\infty}$ & $m$ & $\vec{\nabla}$ & $\frac{\pi}{\sigma}$ & $\infty$ \\
\hline$\underline{\Xi}$ & & $\bar{\nabla}$ & 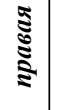 & शे: & 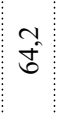 & E & \& & - & & & $\overline{\bar{x}}$ & $\begin{array}{l}\mathbf{E} \\
\mathbb{\Xi} \\
\text { s }\end{array}$ & \&্ల & 8 & $\stackrel{f}{\sim}:$ f & : & $m$ & $\vec{f}$ & $\frac{\partial}{\partial}$ & $\infty$ \\
\hline & & & & 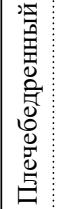 & 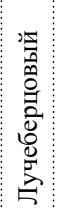 & . & 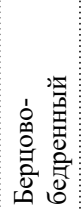 & & & & & & -1 & $n-7$ & $-m$ & - & $n$ & -1 & $\sim$ & $\infty$ \\
\hline & & & & & & 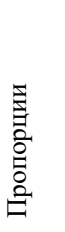 & & 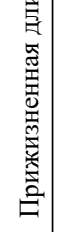 & & 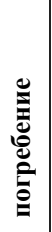 & & & 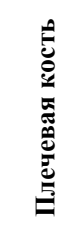 & & 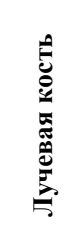 & $\begin{array}{ll}f \\
0 \\
0\end{array}$ & 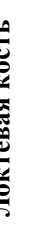 & & 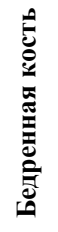 & \\
\hline
\end{tabular}




\begin{tabular}{|c|c|c|c|c|c|c|c|c|c|c|c|c|c|c|}
\hline \multirow{2}{*}{$=$} & \multirow{2}{*}{ in } & \multirow{2}{*}{ 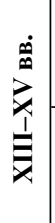 } & క్ & $\stackrel{m}{m}$ & $\stackrel{2}{\sim}$ & & 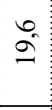 & & $\stackrel{\circ}{2}$ & $\overrightarrow{8}$ & $\stackrel{\circ}{+}$ & & $\stackrel{\forall}{\infty}$ & \multirow{2}{*}{ 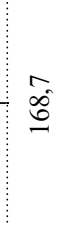 } \\
\hline & & & 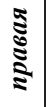 & $\stackrel{R}{n}$ & ম & & $\tilde{a}$ & & $\begin{array}{l}\infty \\
\infty \\
\infty\end{array}$ & $\stackrel{0}{\stackrel{i}{0}}$ & $\begin{array}{l}n \\
n \\
n\end{array}$ & & ळे & \\
\hline \multirow{2}{*}{ 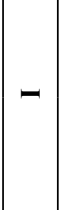 } & \multirow{2}{*}{$q$} & \multirow{2}{*}{ 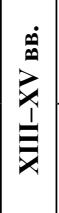 } & ธั้ & ల্ল & $\mathscr{8}$ & $\frac{\infty}{m}$ & $\partial^{\prime}$ & $\stackrel{2}{=}$ & $\stackrel{2}{2}$ & $\stackrel{0}{\ddot{i}}$ & $\stackrel{\infty}{2} \stackrel{m}{?}$ & $\vec{i}$ & $\begin{array}{l}\stackrel{b}{\circ} \\
\stackrel{1}{*}\end{array}$ & \multirow{2}{*}{$\overrightarrow{0}$} \\
\hline & & & 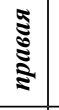 & $m$ & 6 & $\tilde{m}$ & 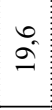 & $\stackrel{0}{=}$ & $\vec{a}$ & $\approx$ & 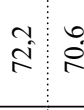 & $\ell^{n}$ & $\stackrel{n}{\infty}$ & \\
\hline \multirow{2}{*}{ D } & \multirow{2}{*}{$\stackrel{\infty}{+}$} & \multirow{2}{*}{ 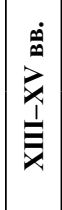 } & ธัँ & $\stackrel{n}{e}$ & $\stackrel{\circ}{\sim}$ & in & $\tilde{\mathrm{n}}$ & $\stackrel{n}{\sim}$ & $\begin{array}{c}\infty \\
\tilde{d}\end{array}$ & $\stackrel{\infty}{\stackrel{\infty}{0}}$ & $\begin{array}{c:c}n & \infty \\
\tilde{2} & b\end{array}$ & $\begin{array}{l}\infty \\
\hat{0}\end{array}$ & $\hat{\infty}$ & \multirow{2}{*}{$\bar{n}$} \\
\hline & & & 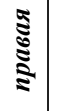 & $\stackrel{b}{n}$ & $\stackrel{0}{\circ}$ & $\vec{n}$ & $\hat{\mathrm{i}}$ & $\infty$ & $\begin{array}{l}n \\
\hat{i}\end{array}$ & $\stackrel{\infty}{\stackrel{i}{1}}$ & $\dot{\vec{t}} \overrightarrow{\vec{\sigma}}$ & $\stackrel{n}{\approx}$ & $\begin{array}{l}n \\
\infty \\
\infty\end{array}$ & \\
\hline \multirow{2}{*}{-} & \multirow{2}{*}{ F } & \multirow{2}{*}{ 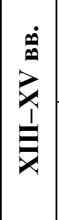 } & కั้ & $\stackrel{\circ}{\stackrel{0}{m}:}$ & 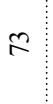 & $m_{m}^{\infty}$ & $\dot{\partial}$ & $\stackrel{0}{2}$ & $\frac{+}{\vec{N}}$ & $\overrightarrow{\vec{\lambda}}$ & $\begin{array}{c}\infty \\
\stackrel{0}{\sim}\end{array}$ & $\stackrel{0}{i}$ & $\tilde{2}$ & \multirow{2}{*}{$\begin{array}{l}0 \\
\dot{8}\end{array}$} \\
\hline & & & 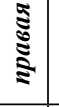 & $\stackrel{n}{m}$ & $\mathbb{N}$ & m & $\dot{2}$ & $\hat{\infty}^{\infty}$ & $\frac{\vec{a}}{\vec{i}}$ & $\hat{\text { iे }}$ & ले & $\hat{i}$ & $\stackrel{+}{\infty}$ & \\
\hline \multirow{2}{*}{-} & \multirow{2}{*}{ ले } & \multirow{2}{*}{ 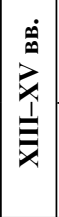 } & $\begin{array}{l}\tilde{3} \\
\stackrel{5}{5} \\
\vdots\end{array}$ & 卢 & $\infty$ & & $\stackrel{\vec{i}}{\mathrm{~d}}$ & $\frac{0}{\vec{N}}$ & $\frac{\pi}{2}$ & $\overrightarrow{\hat{n}}$ & $\begin{array}{l}0 \\
i \\
i\end{array}$ & $\frac{n}{0}$ & $\ddot{\infty}$ & \multirow{2}{*}{ ते } \\
\hline & & & 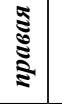 & $\stackrel{+}{m}$ & $\infty$ & $\vec{m}$ & $\hat{a}$ & $\vec{\sim}$ & $\frac{\infty}{\vec{N}}$ & $\overrightarrow{\hat{i}}$ & ì & $\hat{b}^{\infty}$ & $\frac{0}{\infty}$ & \\
\hline \multirow{2}{*}{-} & \multirow{2}{*}{ ले } & \multirow{2}{*}{ 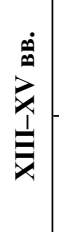 } & 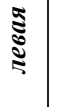 & $\stackrel{\infty}{m}$ & $\approx$ & ने & $\stackrel{+}{2}$ & $0_{0}^{m}$ & $\frac{n}{N}$ & $\hat{\text { iे }}$ & $\begin{array}{c}1 \\
\tilde{N}\end{array}$ & $\dot{\theta}^{\prime}$ & ?. & \multirow{2}{*}{ हิ } \\
\hline & & & 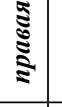 & $\stackrel{D}{n}:^{\prime}$ & $\approx$ & ${ }^{\circ}$ & $\dot{\AA}$ & $\hat{0}$ & $\hat{\tilde{i}}$ & $\stackrel{\infty}{\stackrel{i}{0}}$ & $\hat{i}: \hat{b}$ & $\stackrel{0}{8}$ & $\frac{\dot{\pi}}{\infty}$ & \\
\hline & \multirow[b]{2}{*}{ 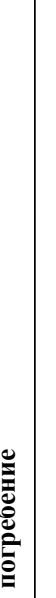 } & & & $-?$ & $\stackrel{8}{2}$ & 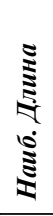 & 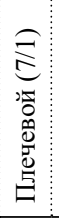 & 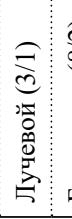 & 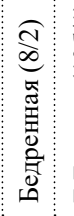 & 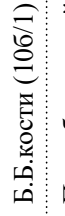 & 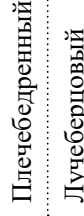 & 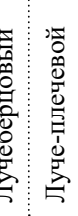 & 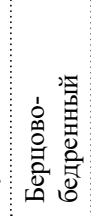 & \multirow[b]{2}{*}{ 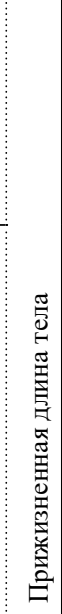 } \\
\hline & & & & 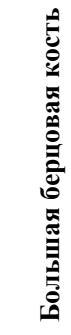 & $\frac{1}{4}$ & 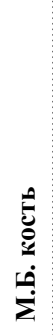 & & \multicolumn{2}{|c|}{ 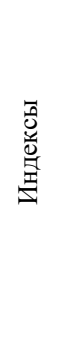 } & & & 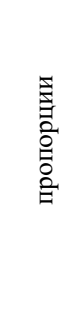 & & \\
\hline
\end{tabular}




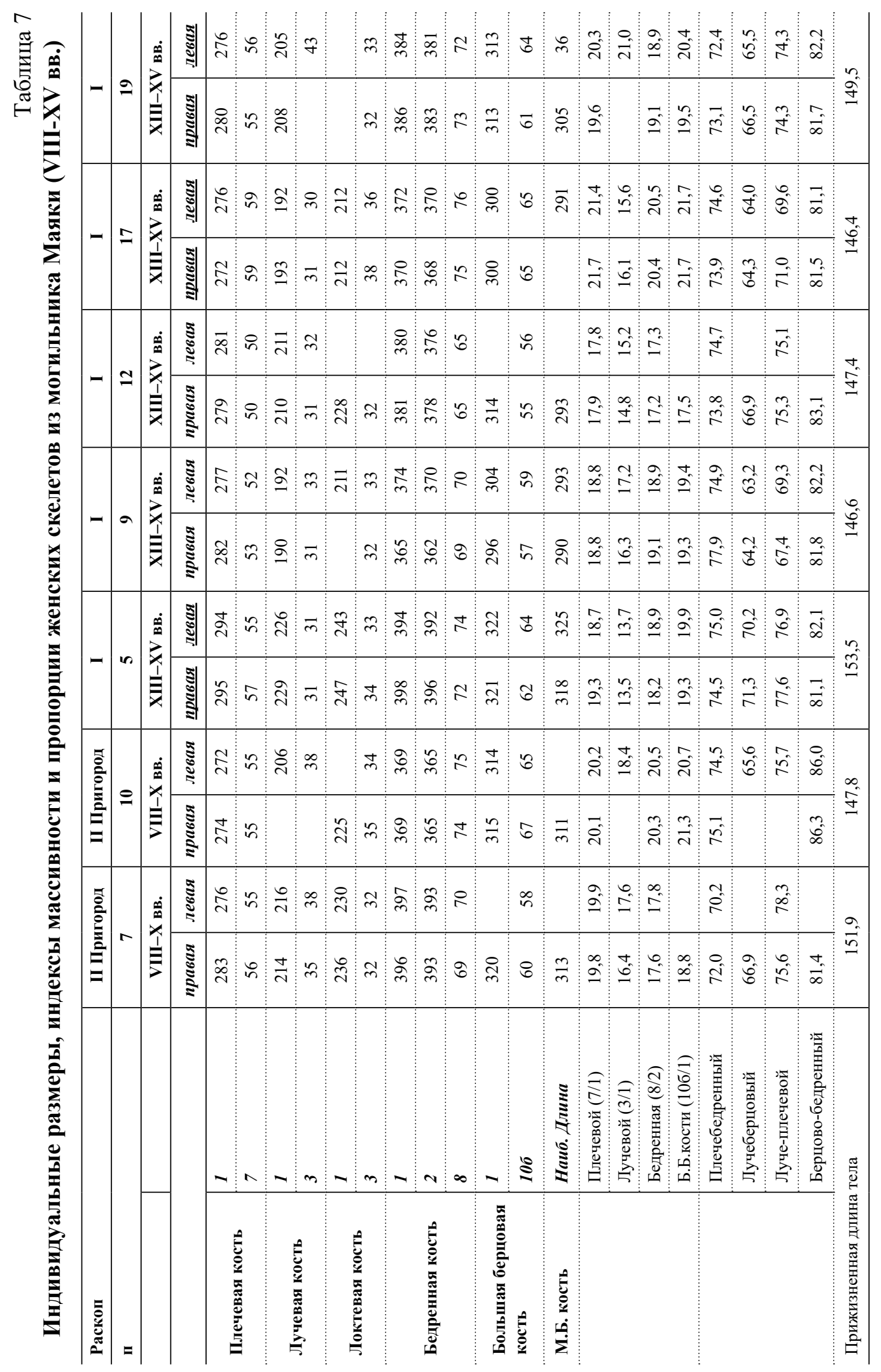




\begin{tabular}{|c|c|c|c|c|c|c|c|c|c|c|c|c|c|c|c|c|c|c|c|c|c|c|c|c|}
\hline \multirow{2}{*}{-} & \multirow{2}{*}{$\begin{array}{l}\text { d } \\
7\end{array}$} & \multirow{2}{*}{ 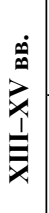 } & ฐู้ & $\begin{array}{l}\infty \\
\infty \\
\sim\end{array}$ & 8 & $\stackrel{\mathrm{N}}{ }$ & లో & $\underset{d}{J}$ & m & $\stackrel{2}{2}$ & $\vec{m}$ & $\infty$ & त్లి & $\infty$ & $\frac{\partial}{m}$ & $\frac{a}{\vec{v}}$ & $\overbrace{0}^{+}$ & $\hat{n}$ & $\frac{m}{v}$ & $\hat{n}$ & $\begin{array}{l}\infty \\
\infty \\
\infty\end{array}$ & tr. & $\underset{\infty}{\infty}$ & \\
\hline & & & 密 & $\stackrel{\varkappa}{\hat{\lambda}}$ & $\hat{6}$ & $\stackrel{\sim}{\AA}$ & $\stackrel{\infty}{m}$ & $\underset{\mathrm{d}}{\mathrm{f}}$ & $m$ & $\stackrel{2}{2}$ & $\vec{m}$ & $\infty$ & $\widetilde{ల}$ & 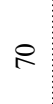 & $\frac{\infty}{m}$ & $\frac{n}{i}$ & فे & $\hat{n}$ & $\hat{\vec{i}}$ & $\stackrel{a}{t}^{\prime}$ & $\hat{~}$ & $\begin{array}{l}\infty \\
\infty^{0}\end{array}$ & \begin{tabular}{c}
\multirow{1}{*}{} \\
$\stackrel{\infty}{0}$
\end{tabular} & \\
\hline \multirow{2}{*}{ 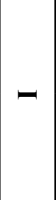 } & \multirow{2}{*}{ f } & \multirow{2}{*}{ 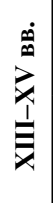 } & ฐั & $\stackrel{\widehat{\imath}}{\hat{\imath}}$ & 8 & $\stackrel{\circlearrowright}{\sim}$ & $\hat{m}$ & $\infty$ & i & $\stackrel{\infty}{\infty}$ & ले & $\infty$ & ల్ల & 6 & $\frac{\infty}{m}$ & $\frac{\vec{v}}{a}$ & $\vec{\Xi}$ & $\hat{\tilde{N}}$ & $\vec{a}$ & $\stackrel{2}{2}$ & $\begin{array}{l}n \\
6\end{array}$ & $\begin{array}{l}0 \\
\infty^{\circ} \\
i\end{array}$ & $\begin{array}{l}\infty \\
\infty^{\circ}\end{array}$ & \\
\hline & & & 气ू & $\stackrel{\grave{\lambda}}{ }$ & 8 & $\stackrel{\infty}{\sim}$ & $\hat{m}$ & $\tilde{\omega}$ & $\ddot{m}$ & \& & $\tilde{m}$ & $\infty$ & $\stackrel{\infty}{\sim}$ & 6 & $\frac{n}{m}$ & $\frac{n}{\vec{N}}$ & $\stackrel{i}{\check{1}}$ & $\stackrel{0}{0}$ & $a^{\infty}$ & $\frac{i}{i}$ & $\begin{array}{l}n \\
8 \\
8\end{array}$ & $\overrightarrow{\infty^{0}}$ & $\stackrel{n}{\infty}$ & \\
\hline \multirow{2}{*}{ 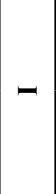 } & \multirow{2}{*}{$\infty$} & \multirow{2}{*}{ 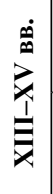 } & ฐู้ & $\underset{\sim}{\sim}$ & $n$ & $\bar{\sim}$ & in & $\vec{\sim}$ & $\bar{m}$ & $\underset{m}{\infty}$ & $\infty$ & $\therefore$ & $\stackrel{\circ}{m}$ & 8 & & $\stackrel{2}{2}$ & $\vec{I}$ & $\stackrel{m}{\stackrel{m}{े}}$ & $\frac{m}{\vec{N}}$ & $\stackrel{2}{\sim}$ & $\overrightarrow{0}$ & $\begin{array}{l}\infty \\
+^{+}\end{array}$ & $\begin{array}{l}0 \\
\vec{\infty}\end{array}$ & \multirow{2}{*}{$\vec{g}$} \\
\hline & & & 密 & $\underset{\sim}{\stackrel{\sim}{\sim}}$ & in & $\stackrel{\circ}{\sim}$ & $\hat{n}$ & $\tilde{\sim}^{2}$ & $\tilde{m}$ & $\underset{\infty}{\infty}$ & $\stackrel{\infty}{m}$ & $\infty$ & $\stackrel{\circ}{m}$ & 6 & ి & ڤ̂े & $\stackrel{\stackrel{2}{-}}{=}$ & $\stackrel{0}{\circ}$ & $\frac{\vec{N}}{\vec{N}}$ & $\stackrel{0}{1}$ & $\hat{\sigma}$ & $\begin{array}{l}n \\
\mathbb{I}^{2}\end{array}$ & $\begin{array}{l}0 \\
\text { i }\end{array}$ & \\
\hline & \multirow{2}{*}{ లా } & \multirow{2}{*}{ 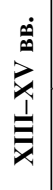 } & ฐั้ & $\stackrel{\infty}{\infty}$ & $i n$ & $\stackrel{m}{\sim}$ & $\ddot{m}$ & तె & i & $\stackrel{\leftrightarrow}{q}$ & 字 & 2 & లి & 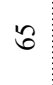 & & $\frac{a}{2}$ & ठ́ & $\stackrel{\circ}{9}$ & $\stackrel{m}{\stackrel{n}{A}}$ & ถ્ & 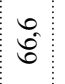 & $\tilde{s}^{2}$ & $\stackrel{2}{2}$ & \multirow{2}{*}{ 党 } \\
\hline & & & 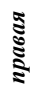 & 鬲 & $i$ & $\stackrel{\sim}{\sim}$ & $\ddot{m}$ & సี & 凩 & के & $\hat{q}$ & $\infty$ & $\frac{b}{m}$ & t & 今े & $t_{\infty}^{+}$ & 6 & 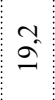 & $\hat{n}$ & से & $\begin{array}{c}0 \\
\infty \\
\infty\end{array}$ & $\begin{array}{l}n \\
n^{\prime}\end{array}$ & $\begin{array}{l}0 \\
\stackrel{2}{\approx}\end{array}$ & \\
\hline \multirow{2}{*}{ 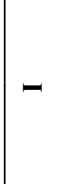 } & \multirow{2}{*}{$\mathscr{4}$} & \multirow{2}{*}{ 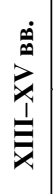 } & ฐู้ & ন & $\tilde{n}$ & $\stackrel{\circ}{\sim}$ & $m$ & $\mathbb{N}$ & i & \& & $\stackrel{\infty}{2}$ & $\infty$ & $\underset{\sim}{\mathbb{N}}$ & t & & $\begin{array}{c}0 \\
\infty\end{array}$ & $\stackrel{m}{2}$ & $\overrightarrow{\mathrm{n}}$ & $a^{2}$ & $\stackrel{\rho}{े}^{\prime}$ & $\overrightarrow{6}$ & $n^{n}$ & के & \multirow{2}{*}{ กิ } \\
\hline & & & 密 & ๙ั & $n$ & $\vec{\sim}$ & ఉ & $\tilde{N}$ & নे & बे & வ & $\infty$ & $\stackrel{n}{\infty}$ & 6 & & $\infty^{\infty}$ & $\hat{n}$ & है & ì & $\stackrel{n}{+2}$ & $\delta^{\infty}$ & $\stackrel{\circ}{\stackrel{2}{n}}$ & $\vec{a}$ & \\
\hline & \multirow{2}{*}{$\approx$} & \multirow{2}{*}{ 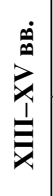 } & ฐู้ & ల్ల & $\stackrel{\infty}{n}$ & $\hat{\sim}$ & D & $\infty$ & $m$ & $\stackrel{n}{5}$ & $\stackrel{+}{+}$ & $\infty$ & D & $\therefore$ & 웅 & $\stackrel{\infty}{=}$ & $\stackrel{2}{2}$ & $\begin{array}{c}m^{2} \\
\infty^{\prime}\end{array}$ & 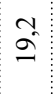 & $\stackrel{\infty}{i}$ & $\frac{\overrightarrow{6}}{6}$ & $\hat{\tilde{n}}$ & $\stackrel{\text { O̦ }}{\infty}$ & \multirow{2}{*}{$\overrightarrow{0}$} \\
\hline & & & 焉 & 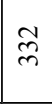 & in & ते & $\stackrel{m}{m}$ & ర్d & मे & $\sqrt[n]{q}$ & $\stackrel{n}{5}$ & $\infty$ & : & $尺$ & in & $\stackrel{\infty}{\perp}$ & $\stackrel{\infty}{ \pm}$ & $\begin{array}{l}n \\
\infty \\
\infty\end{array}$ & $\overrightarrow{2}$ & $\stackrel{0}{i}$ & $\hat{n}$ & î & $\stackrel{+}{\circ}$ & \\
\hline \multirow[t]{2}{*}{ - } & \multirow{2}{*}{$\bar{N}$} & \multirow{2}{*}{ 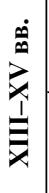 } & ฐัँ & & in & (ి) & ల్ల & $\tilde{N}$ & ల & $\stackrel{P}{\stackrel{2}{n}}$ & $\underset{n}{8}$ & $\infty$ & $\frac{\infty}{m}$ & 5 & & & $\stackrel{2}{2}$ & ते & $\overrightarrow{\vec{i}}$ & & $\delta_{0}^{\infty}$ & & $\begin{array}{l}\hat{b} \\
\text { के }\end{array}$ & \multirow{2}{*}{\begin{tabular}{l}
$\infty$ \\
\multirow{a}{\pm}{}
\end{tabular}} \\
\hline & & & $\begin{array}{l}\text { ș } \\
\text { ș }\end{array}$ & $\stackrel{尺}{\sim}$ & $\stackrel{\infty}{n}$ & & & & নे & $\stackrel{\infty}{0}$ & $\stackrel{n}{8}$ & $\infty$ & $\underset{\sim}{~}$ & 8 & & $\frac{n}{n}$ & & $\overrightarrow{\vec{v}}$ & $\frac{0}{\vec{N}}$ & $\begin{array}{l}0 \\
+1\end{array}$ & & & $\stackrel{\hat{\infty}}{\hat{\infty}}$ & \\
\hline \multirow[b]{2}{*}{ 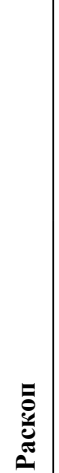 } & & & & - & $n$ & -1 & $n$ & -1 & $n$ & - & $\nu$ & $\infty$ & - & $\stackrel{8}{\circledR}$ & 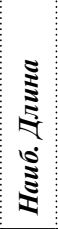 & 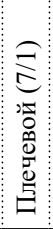 & 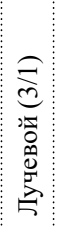 & 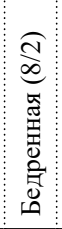 & 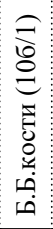 & 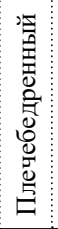 & 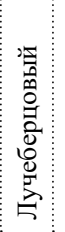 & 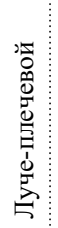 & 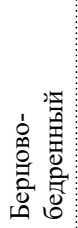 & $\underset{5}{5}$ \\
\hline & $=$ & & & 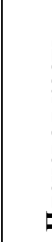 & 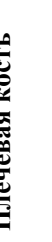 & 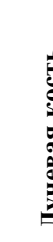 & है. & & 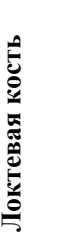 & & 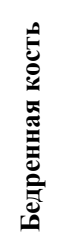 & & 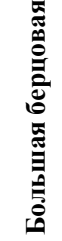 & & 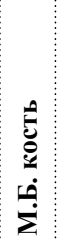 & & & & & & & & & 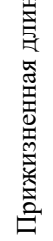 \\
\hline
\end{tabular}




\section{Таблица 7 (окончание)}

\begin{tabular}{|c|c|c|c|c|c|c|c|}
\hline \multicolumn{2}{|l|}{ Раскоп } & \multicolumn{2}{|c|}{$\mathbf{I}$} & \multicolumn{2}{|c|}{ I } & \multicolumn{2}{|c|}{$\mathbf{I}$} \\
\hline \multicolumn{2}{|l|}{ II } & \multicolumn{2}{|c|}{45} & \multicolumn{2}{|c|}{46} & \multicolumn{2}{|c|}{47} \\
\hline & & \multicolumn{2}{|c|}{ XIII-XV вв. } & \multicolumn{2}{|c|}{ XIII-XV вв. } & \multicolumn{2}{|c|}{ XIII-XV вв. } \\
\hline & & правая & левая & правая & левая & правая & левая \\
\hline \multirow{2}{*}{ Плечевая кость } & 1 & 280 & 273 & 284 & 280 & 314 & 309 \\
\hline & 7 & 55 & 55 & 58 & 56 & 64 & 63 \\
\hline \multirow{2}{*}{ Лучевая кость } & 1 & 212 & 214 & 220 & 215 & 244 & 240 \\
\hline & 3 & 35 & 33 & 35 & 35 & 41 & 42 \\
\hline \multirow{2}{*}{ Локтевая кость } & 1 & 232 & & 239 & 236 & 262 & 258 \\
\hline & 3 & 31 & & 34 & 34 & 40 & 39 \\
\hline \multirow{3}{*}{ Бедренная кость } & 1 & 388 & 385 & 379 & 373 & 430 & 430 \\
\hline & 2 & 384 & 382 & 378 & 373 & 425 & 428 \\
\hline & 8 & 75 & 76 & 83 & 83 & 83 & 83 \\
\hline \multirow{2}{*}{ Большая берцовая кость } & 1 & 317 & 319 & 322 & 322 & 361 & 359 \\
\hline & $10 \sigma$ & 62 & 62 & 65 & 67 & 71 & 70 \\
\hline \multirow[t]{9}{*}{ М.Б. кость } & Наиб. Длина & 309 & 310 & 315 & 310 & & \\
\hline & Плечевой (7/1) & 19,6 & 20,1 & 20,4 & 20,0 & 20,4 & 20,4 \\
\hline & Лучевой (3/1) & 16,5 & 15,4 & 15,9 & 16,3 & 16,8 & 17,5 \\
\hline & Бедренная (8/2) & 19,5 & 19,9 & 22,0 & 22,3 & 19,5 & 19,4 \\
\hline & Б.Б.кости $(10 б / 1)$ & 19,6 & 19,4 & 20,2 & 20,8 & 19,7 & 19,5 \\
\hline & Плечебедренный & 72,9 & 71,5 & 75,1 & 75,1 & 73,9 & 72,2 \\
\hline & Лучеберцовый & 66,9 & 67,1 & 68,3 & 66,8 & 67,6 & 66,9 \\
\hline & Луче-плечевой & 75,7 & 78,4 & 77,5 & 76,8 & 77,7 & 77,7 \\
\hline & $\begin{array}{l}\text { Берцово- } \\
\text { бедренный }\end{array}$ & 82,6 & 83,5 & 85,2 & 86,3 & 84,9 & 83,9 \\
\hline \multicolumn{2}{|l|}{ Прижизненная длина тела } & \multicolumn{2}{|c|}{150,3} & \multicolumn{2}{|c|}{150,7} & \multicolumn{2}{|c|}{160,3} \\
\hline
\end{tabular}

\section{Научная литература}

Артамонова О.А. Могильник Саркела - Белой Вежи // МИА №109. М.: Наука, 1963. 216 с. Артюшенко A.T. Растительность лестостепи и степи Украины в четвертичном периоде. Киев: Наукова думка, 1970. 172 с.

Михеев В.К. Подонье в составе Хазарского каганата. Харьков: Вища школа, 1985. 148 с.

Ходжайов Т.К., Швеиов М.Л., Ходжайова Г.К., Фризен С.Ю. Население Подонцовья эпохи Золотой Орды (по материалам могильников у села Маяки) // Степи Европы в эпоху средневековья. Том 11. Золотоордынское время. Труды по археологии. Сборник научных работ. Донецк: ДонНУ, 2012. С. 125-196.

Швецов М.Л. Погребение 40 могильника «Зливки» // Проблемы истории и археологии Украины. Харьков: ХИАО, 2001. С. 110.

Швецов М.Л. Взаимоотношения степного и лесостепного населения в эпоху раннего средневековья (на примере Подонцовья - Приазовья) // Археологическое изучение Центральной России. Липецк: ЛГПУ, 2006.

Швецов М.Л., Приходнюк О.М. Отчет об археологических работах Донецкой археологической экспедиции в 1989 г. // НА ИА НАНУ №53/1990. 
Khojayov Telman K., Khodzhayova Galshira K., Frizen Sergey Y.

\section{A Bioanthropological Study of the Burial Grounds of Donetsk and Lugansk regions. Part I}

\section{DOI: $10.33876 / 2311-0546 / 2021-4 / 357-381$}

The article is devoted to the craniological materials from the Mayaki burial ground, Donetsk region. It describes the archaeological site and the funeral rite and features the results of the bioanthropological study. The main goal is to introduce the individual craniological data from the burial ground.

Keywords: craniology, bioanthropology, the Middle Ages, burial rite, archaeological complex

For Citation: Khojayov, T.K., G.K. Khodzhayova, and S.Y. Frizen. 2021. A Bioanthropological Study of the Burial Grounds of Donetsk and Lugansk regions. Part I. Herald of Anthropology (Vestnik Antropologii) 4: 357-381.

Authors info: Khojayov Telman K. - Chief Researcher, Doctor of History. Center for Physical Anthropology, IEA RAS, Moscow. E-mail: telmkas@yandex.ru.

Khodzhayova Galshira K. - Independent researcher, Doctor of History, Moscow. E-mail: telmkas@yandex.ru.

Frizen Sergey Y. - Researcher, Ph.D., Center for Physical Anthropology, IEA RAS, Moscow. E-mail: frizents@iea.ras.ru

The research was carried out within the framework of the research topic «The evolutionary continuum of the genus Homo». Sub-topic «Anthropology of ancient and modern populations»»

\section{References}

Artamonova, O.A. 1963. Mogil'nik Sarkela - Beloi Vezhi [Burial ground of Sarkel - Belaya Vezha]. MIA 109. Moskow: Nauka.

Artiushenko, A.T. 1970. Rastitel'nost'lestostepi i stepi Ukrainy v chetvertichnom periode [Vegetation of the steppe and steppe of Ukraine in the Quaternary period]. Kiev: Naukova dumka.

Mikheev, V.K. 1985. Podon'e v sostave Khazarskogo kaganata [Podonye as a part of the Khazar Khaganate]. Kharkov: Vishcha shkola.

Khodzhaiov, T.K., M.L., Shvetsov, G.K., Khodzhaiova, S.Yu., and Frizen. 2012. Naselenie Podontsov'ia epokhi Zolotoi Ordy (po materialam mogil'nikov u sela Maiaki) [Population of Podontsovye of the era of the Golden Horde (based on materials from burial grounds near the village of Mayaki)]. Stepi Evropy v epokhu srednevekov'ia. Vol. 11. Zolotoordynskoe vremia. Trudy po arkheologii. Sbornik nauchnykh rabot. Donetsk: DonNU.

Shvetsov, M.L., 2001. Pogrebenie 40 mogil'nika “Zlivki” [Burial of 40 Zlivky cemetery]. Problemy istorii i arkheologii Ukrainy. Kharkov: KhIAO.

Shvetsov, M.L., 2006. Vzaimootnosheniia stepnogo i lesostepnogo naseleniia v epokhu rannego srednevekov'ia (na primere Podontsov'ia - Priazov'ia) [The relationship of the steppe and forest-steppe population in the early Middle Ages (on the example of Podontsovye - Azov region)]. Arkheologicheskoe izuchenie Tsentral'noi Rossii. Lipetsk: LGPU.

Shvetsov, M.L., and O.M., Prikhodniuk. 1990. Otchet ob arkheologicheskikh rabotakh Donetskoi arkheologicheskoi ekspeditsii $v 1989 \mathrm{~g}$. [Report on the archaeological work of the Donetsk archaeological expedition in 1989]. NA IA NANU 53 (1990). 
(С) Н.Н. Захарьева, И.Д. Коняев, И.В. Абдрахманова

\title{
ВЛИЯНИЕ ПСИХОЭМОЦИОНАЛЬНОГО НАПРЯЖЕНИЯ НА ПСИХОФИЗИОЛОГИЧЕСКИЕ ХАРАКТЕРИСТИКИ И ФИЗИЧЕСКИЕ КАЧЕСТВА ТАНЦОРОВ И ТАНЦОВЩИЦ ВЫСОКОЙ КВАЛИФИКАЦИИ
}

\begin{abstract}
Проведено обследование 96 спортсменов-танцоров высокой квалификации (50 мужчин и 46 женщин) в подготовительном периоде спортивной подготовки. По результатам анкетирования и психофизиологического тестирования с использованием тестов: TMAS (Taylor manifest anxiety scale), Ч.Д. Спилбергер - Ю.Л. Ханин, «Индивидуальная минута» таниоры распределены по психоэмочиональному напряжению на 3 группь: Grl - низкий уровень (n=40; муж - 24 чел. и жен - 16 чел.); Gr2 - средний уровень (n=39; муж - 19 чел. $и$ жен - 20 чел.); Gr3 - высокий уровень (n=17; муж - 7 чел. и жен - 10 чел.). Для дифференцирования уровней психоэмочионального напряжения танцоров высокой квалификачии без учета половых различий рекомендованы психофизиологические тесты:: TMAS; «Реакиия на звук правой рукой»; «Простая зрительно-моторная реакция» и тест физической работоспособности $P W C_{170^{\circ}}$ У танцовщиц-женщин с различным уровнем психоэмоционального напряжения установлены достоверные отличия в группах сравнения в тестах: "Реакциия на звук», выполненная правой рукой ( $><0,001)$; «Воспроизведение временного интервала со звуковым сигналом», «Оченка величины углов» $(p<0,05)$. У танцоров-мужчин с различным уровнем психоэмочионального напряжения установлены достоверные отличия в тестах: $P W C_{170}(p<0,05)$ и теппинг тесте (1-я и 2-я попытка). Танцуоры, имеющие высокое психоэмоциональное напряжение, имеют самые низкие значения физической работоспособности в группах сравнения, что может обуславливать их низкую $р$
\end{abstract}

Ключевые слова: спортивные бальные танцы, умственная работоспособность, физическая работоспособность, функииональное состояние, пространственно-временные характеристики нервной системы, танц̧оры, танцฺовщчиць

Захарьева Наталья Николаевна - профессор кафедры физиологии Федерального государственного бюджетного образовательного учреждения высшего образования «Российский государственный университет физической культуры, спорта, молодежи и туризма (ГЦОЛИФК)». (Москва, Сиреневый бул. 4, стр.4). E-mail: zakharyeva.natalia@mail.ru

Коняев Илья Дмитриевич - аспирант кафедры физиологии Федерального государственного бюджетного образовательного учреждения высшего образования «Российский государственный университет физической культуры, спорта, молодежи и туризма (ГЦОЛИФК)». (Москва, Сиреневый бул. 4, стр.4). E-mail: Ilya.konyaev@mail.ru

Абдрахманова Ирина Владимировна - доцент кафедры анатомии и физиологии ФГБОУ ВПО «Волгоградская государственная академия физической культуры». (Волгоград, просп. им. В.И. Ленина, 78). E-mail: abdr-iren@yandex.ru 